\title{
O PROCESSO CONSTITUINTE BRASILEIRO, A TRANSIÇÃO E O PODER CONSTITUINTE
}

Cicero Araujo

A experiência constitucional brasileira quase sempre suscita complicados exercícios às teorias jurídicas que se valem do conceito de "Poder Constituinte" e das distinções que dele se seguem. Geralmente, as complicações começam assim: que circunstâncias concretas justificam sua aplicação? Por que, como e sob quais critérios empíricos se pode afirmar que há um poder constituinte? Em vista da capacidade das cartas modernas de receber revisões de maior ou menor envergadura, costuma-se distinguir, dentro do próprio conceito, entre um "poder originário" e um "poder derivado". A partir daí, envereda-se para a discussão de critérios para reconhecer um ou outro, os quais apontam para questões de fato. De modo que, para reivindicar um poder originário, há que se constatar "ruptura institucional" ou "decadência" de certo regime político, credenciando os representantes desse poder - dada sua natureza "ilimitada" e "incondicionada" -, a fazer virtualmente qualquer coisa, inclusive criar uma

\footnotetext{
${ }^{1}$ Ilimitada: "o Poder Constituinte não tem de respeitar limites postos pelo direito positivo anterior"; incondicionada: "o que quer dizer que a nação não está sujeita a qualquer forma prefixada para manifestar a sua vontade; não tem ela que seguir qualquer procedimento determinado para realizar a sua obra de constitucionalização" (Ferreira Filho, 2007, pp. 14-5).
} 
nova constituição. Fora essas situações muito especiais, só haveria espaço para um poder derivado, isto é, de emendamento da constituição em vigor e, por isso, obrigado a observar as normas que definiriam seus limites. Tais normas estariam, ainda, condicionadas a interpretação por um tribunal constitucional (caso existisse) - o que significaria a possibilidade de interferência desse órgão, nos termos, normalmente muito vagos, previstos pela lei constitucional antecedente, considerada "superior".

Assim, além do ponto problemático de derivar de uma simples questão de fato um ato de grande densidade normativa, um mesmo critério poderia justificar, e igualar, gestos históricos muito diversos: desde um movimento de desobediência civil generalizada até um golpe de Estado promovido por uma casta militar. O rígido formalismo dessas teorias só tende a torná-las cegas a essas diferenças, por vezes cruciais na história de um país. Insensíveis 328 ao conteúdo de valor que possa existir em tipos contraditórios de "ruptura" ou "continuidade", "decadência" ou "estabilidade", acabam providenciando idêntica escora jurídica a contestações políticas de sentidos diametralmente opostos, como as de teor autoritário ou democrático. Mas também a continuidades institucionais das mais diversas tonalidades que, porém, dependendo de suas peculiaridades sutis, podem significar a diferença entre o entrave e o desentrave de uma crise política.

Não se trata, no entanto, de criticar essas teorias em suas minúcias. O que se pretende neste artigo é explorar caminho alternativo e propor uma interpretação da experiência política brasileira que levou ao nosso último processo constituinte e à promulgação da Constituição Federal em 1988. Assim se fará, tentando abarcar um espectro mais amplo de questões conceituais, porém mais sensíveis às singularidades dessa experiência histórica e aos valores que orientaram as iniciativas dos atores. Também não se trata de 
pôr em questão o próprio conceito de Poder Constituinte que, ao ver deste articulista, ainda poderia servir como bom candidato a ancorar, em momentos de transformação ou inflexão de regimes políticos, o ideal de soberania popular que está na base das teorias democráticas. Se não em todas, ao menos o que está nas teorias chamadas "normativas", isto é, as que pretendem interpretar os regimes democráticos existentes à luz de valores ético-políticos, como a igualdade e a liberdade. Mesmo nesse campo, a reflexão que segue pede algumas adaptações para que dê conta de contextos fluidos, como os que caracterizam uma transição de regimes políticos.

O desafio é interpretar o conceito de Poder Constituinte de modo suficientemente moldável à contingência dos eventos históricos e com um caráter mais difuso do que se costuma fazer em termos de protagonismo, evitando sua fixação num agente privilegiado que venha a pretender sua encarnação. Tal fixação é uma tendência das teorias jurídicas a que se aludiu e recorrentemente dá margem a apropriações autoritárias, como aconteceu logo no advento do regime que se instalou no Brasil em 1964. A análise dessa experiência e, depois, da transição à democracia até a abertura do processo constituinte, poderá ajudar a estabelecer esse ponto. Antes, porém, de tomar essa questão, cabe recapitular a discussão jurídica que se deu no início daquele processo.

\section{Constituinte, Constituição e o debate jurídico brasileiro}

Aceitemos, convencionalmente, que o último processo constituinte no Brasil tenha se iniciado com o debate sobre a convocação da Assembleia Nacional Constituinte, proposta pelo presidente da República e submetida ao Congresso, em junho de 1985. Também convencionalmente tomemos como seu encerramento a proclamação da Constituição Federal, em outubro de 1988. Diz-se "convencionalmente", pois essa 
demarcação temporal é algo arbitrária, uma vez que o debate sobre o assunto é anterior ao projeto de emenda constitucional à Carta de 1967/1969, apresentado pelo presidente José Sarney $^{2}$, e com o qual se fez aquela convocação. Além disso, a questão da forma definitiva da Constituição permaneceu aberta ainda durante a década de 1990, por conta do processo de revisão, previsto nas disposições transitórias do texto aprovado em 1988. Mas fixemo-nos nessa demarcação para não ficarmos sem um quadro de referência.

Como não poderia deixar de ser, vários juristas foram chamados, ou se sentiram chamados, a intervir no debate de 1985. A história é bem conhecida: o que se convoca, por que se convoca e como se convoca uma assembleia constituinte? Enfim, qual é a sua forma correta? O debate entre os juristas, como dito, é anterior, ecoando algumas vezes no Congresso Nacional $^{3}$ e atingindo, de fato, a opinião pública mais ampla, apenas a partir do momento em que Tancredo 330 Neves, eleito presidente da república, assume em seu programa de governo a tarefa de convocar a assembleia para elaborar uma nova Constituição para o país. Com a morte de Tancredo, seu sucessor José Sarney herda a tarefa.

Nas mãos dos juristas, o debate voltará a acionar as teorias constitucionais em voga, notadamente nos termos mencionados no início deste trabalho. Os que defendiam que a assembleia a ser convocada deveria ser entendida

\footnotetext{
${ }^{2} \mathrm{O}$ projeto resultou na Emenda Constitucional n. 26, de 27 de novembro de 1985. Que o debate é anterior, se entrevê no pequeno ensaio publicado por Raymundo Faoro, em 1981. Para um retrospecto do debate, ver também a coletânea de artigos de autoria de Miguel Reale (1985).

${ }^{3}$ Como foi o caso da exposição feita por Afonso Arinos de Melo Franco (que na época não era parlamentar), a convite da comissão de constituição e justiça do Senado Federal, em agosto de 1981 (Franco, 1982). Sua proposta de que o Congresso aprovasse uma "resolução legislativa", à revelia do Poder Executivo, para convocar uma "Constituinte instituída" - isto é, autoatribuindo-se funções constituintes - gerou controvérsia no seio dos próprios juristas simpáticos à ditadura, culminando numa polêmica pública entre Arinos e Miguel Reale, nas páginas do Jornal do Brasil, em dezembro de 1982.
} 
como expressão de um "poder derivado", e não de um "poder originário", levavam a óbvia vantagem de apontar, como questão de fato, a continuidade institucional: a estrutura de governo que a convocava - o presidente da República e o próprio Congresso, tendo na retaguarda o Supremo Tribunal Federal - provinha da ordem constitucional posta até então. Embora sua origem fosse autoritária, as coisas seguiam mais ou menos conforme suas normas, porém reinterpretadas. Longe de uma iniciativa "revolucionária" e "rupturista", portanto, o que se haveria de fazer era uma ampla reforma da Constituição existente. Exatamente por isso, seus poderes e atribuições não deveriam ser ilimitados. Nas palavras de um jurista que apresentou uma defesa detalhada, e muito citada, dessa posição: "a Nova República não nasceu de uma revolução, surgiu do exato cumprimento da Constituição em vigor. Não lhe é dado, em consequência, invocar o Poder Constituinte revolucionário. Não detém Poder Constituinte originário. E o terreno em que pisa é movediço demais para que ouse quebrar a Constituição, visto que esta é seu título ao Poder" (Ferreira Filho, 2007, p. 159) ${ }^{4}$.

Sem dúvida, houve juristas que, a partir de um campo que poderia ser denominado "radical-democrático", procuraram evidenciar outras questões de fato, que não a dicotomia continuidade/ruptura institucional. Essa é a linha seguida por, entre outros, José Afonso da Silva - que terá um papel importantíssimo na elaboração da futura Carta -, ao enfatizar a não menos óbvia "decadência” do regime de 1964 para justificar a presença de um poder constituinte "originário" no processo e não simplesmente de um "derivado" . Mais ou menos no mesmo sentido se dá a fina

\footnotetext{
${ }^{4}$ Essa citação integra a parte IV do livro, capítulo único, onde está a discussão relevante.

${ }^{5}$ Ver o artigo "Constituinte", publicado por Silva (2000, pp. 66-81), escrito originalmente no início de 1986, como roteiro para os debates de que o autor participou naquele ano.
} 
argumentação de Raymundo Faoro, cujo ensaio de 1981 (mencionado em nota anterior) foi várias vezes reeditado no período, e que sustenta a tese da assembleia constituinte de plenos poderes com base não na ruptura revolucionária, mas no fato da "decomposição de legitimidade" do regime. No fundo, dizia ele, era para evitar tal ruptura, e não por ser uma consequência dela, que se deveria convocar uma assembleia constituinte ${ }^{6}$.

É evidente que, para além das filigranas jurídicas, a linha de argumento dos advogados do campo conservador soava como um insulto a toda a luta que a oposição ao regime autoritário havia travado no longo período antecedente, que culminou numa adesão de quase todas as forças políticas à campanha das "Diretas-Já" e, em seguida, na eleição de um candidato de seu campo no colégio eleitoral da ditadura. Uma Assembleia Nacional Constituinte, "livre, soberana e exclusiva", como dizia a militância democráti332 ca da época - isto é, sem a tutela da ordem constitucional imposta pelo regime autoritário, mesmo a tutela dos políticos oposicionistas, que haviam feito suas carreiras durante sua plena vigência - seria o desdobramento natural dessa luta que, mesmo aos trancos e barrancos, havia sido vencida pela oposição.

Enquanto discurso estritamente político, se consideradas as disposições da opinião pública predominantes no período, nada favoráveis às persistências do antigo regime, essa resposta parecia muito persuasiva. Contudo, no âmbito jurídico, era um argumento que tinha mais dificuldade de se assentar, especialmente diante da rigidez formal das teorias

\footnotetext{
6 "Não é a ruptura do poder que reclama a constituinte, para legitimá-lo, qualquer que seja seu conteúdo. É a legitimidade em decomposição, agravada pela ineficiência, que desperta o Poder Constituinte de um povo" (Faoro, 2007, p. 219). [Esse ensaio de Faoro foi publicado originalmente em 1981, com o título "Assembleia Constituinte: a legitimidade recuperada”]. Ver também Bonavides (1985), capítulos XII e XIII.
} 
de poder constituinte aceitas, cujo critério decisivo tinha por base exatamente as questões de fato antes mencionadas. Argumentar nesse terreno, como o faziam também os juristas de oposição mais combativos - e estes o faziam porque enxergavam a força emancipatória da ideia de poder constituinte, ideia curiosamente compartilhada por ambos os lados da contenda, mas que o lado adversário não aceitava aplicar nas circunstâncias brasileiras - argumentar nesse terreno, dizia-se, colocava esses atores/autores numa posição um tanto embaraçosa e desorientadora. Embaraçosa porque, de partida não rejeitavam que o Congresso Nacional vigente fosse a instância, senão inteiramente legítima, pelo menos aceitável, para convocar a assembleia. Todavia, aquele Congresso - cujo senado ainda se compunha, no momento do debate, pelos famosos "senadores biônicos" (indicados pelo establishment civil-militar e não eleitos pelo povo) já não era, ele mesmo, uma persistência do antigo regime? E desorientadora, porque a possibilidade do não endosso de sua tese jurídica os levava a um tudo ou nada político: ou a assembleia haveria de ser "livre, soberana e exclusiva" para elaborar uma autêntica Constituição ou, ao contrário, renunciando à representação de um poder constituinte pleno, nada mais poderia ser do que um arranjo para amordaçar esse último, com isso esvaziando de sentido democrático tudo que resultasse dele, até mesmo a futura Constituição. Em suma: aceita sua rigidez formal, teorias constitucionais com essa feição pareciam desarmar aqueles que, a partir de um campo inequivocamente democrático, pretendessem influenciar os trabalhos de uma assembleia que, de um jeito ou de outro, estava fadada a acontecer.

Mas tão logo se percebeu que esse evento, fosse como fosse, se tornaria fato político de primeira grandeza, os atores mais engajados, também entre os juristas, deixaram de insistir nesse formalismo, para enveredar em considerações táticas ou estratégicas sobre a melhor maneira de participar 
daquele embate ${ }^{7}$. À primeira vista, a emenda constitucional que aprovou a convocação da assembleia parecia beneficiar mais um lado da disputa do que o outro: nas deliberações parlamentares prevaleceu a tese de que o futuro Congresso, cuja maioria dos representantes - exceto o terço de senadores eleito em 1982 - seria escolhida no pleito do ano seguinte, deveria funcionar ao mesmo tempo como órgão legislativo ordinário e como instância constituinte. Contudo, essas mesmas deliberações reconheceram que a assembleia haveria de ser "livre e soberana" para elaborar uma nova constituição, o que pelo menos desmanchava a ideia de que sua tarefa seria apenas "emendar" a ordem até então vigen$\mathrm{te}^{8}$. Essas ambiguidades revelavam o quanto aquelas teorias constitucionais, a despeito de suas divergências recíprocas nos pontos acima assinalados, não conseguiam abarcar satisfatoriamente os interesses e os valores em jogo.

\section{A relevância da transição}

Até aqui não se discutiu como as peculiaridades da transição à democracia no Brasil, e as diferentes avaliações sobre ela, influenciaram os debates. Certamente influenciaram e muito. Mas é preciso insistir neste ponto: elas impactaram o debate jurídico apenas como elemento subsidiário para fixar aquelas mesmas questões de fato: ruptura ou continuidade, decadência ou vigor, legitimidade ou ilegitimidade? Justamente em relação a esses pontos, o enquadramento teórico dificultava uma resposta nuançada, induzindo a opções esquemáticas do tipo "ou uma coisa ou outra”. Contudo, a transição brasileira, longa como foi, revelou-se tão cheia de

\footnotetext{
${ }^{7}$ Para um relato, ver Michiles et al. (1989, pp. 37-59). Uma manifestação muito rica desse debate pode ser encontrada na coletânea editada por Fortes e Nascimento (1987), em particular na segunda parte. A coletânea é resultado de um colóquio ocorrido na Faculdade de Filosofia, Letras e Ciências Humanas (FFLCH) da USP, em maio de 1986.

${ }^{8}$ Ver Emenda Constitucional n. 26, Art. $1^{\circ}$, em www.senado.gov.br/publicacoes/ anais/constituinte/emenda26-85.pdf .
} 
zigue-zagues que dificilmente poderia ser reduzida a avaliações esquemáticas. Mesmo quem, ao fim e ao cabo, fizesse uma avaliação essencialmente negativa do processo - negativa do ponto de vista democrático -, teria de resgatar certos aspectos positivos que, para o embate futuro, não poderiam ser desprezados. E isso tinha consequências diretas na decisão de participar e intervir com ânimo na questão constituinte, a despeito do fato de que a forma de sua convocação, aprovada pelo Congresso, pudesse reforçar a avaliação negativa.

Para os que faziam uma avaliação positiva, mesmo entre os desapontados com aquela decisão do Congresso, a relevância e o entusiasmo para participar eram, obviamente, imediatos, ainda que tivessem de pesar com muito cuidado os "retrocessos" da jornada. As avaliações mais nuançadas, às vezes divergentes entre si, tinham de inserir, entre o negativo e o positivo, zonas de lusco-fusco que permitiam maior ou menor flexibilidade na intervenção política. $\mathrm{Na}$ verdade, esse último padrão de comportamento era induzido pelas ambiguidades da própria transição, em seus "avanços" e "retrocessos" - ambiguidades que sugeriam a todos os atores um horizonte de indeterminação do processo. E quanto mais indeterminado fosse, maior o empuxo para participar dele, criticamente ou não.

Ainda não é possível precisar - se é que o será no futuro - o quanto a comparação com as transições à democracia, ocorridas em outros países mais ou menos na mesma época, influenciou essas diferentes avaliações. Colocando entre parênteses essa informação, é no mínimo curioso indagar como esse dado poderia nuançar ainda mais as avaliações da experiência brasileira e até suscitar questionamentos a respeito dos critérios factuais adotados no debate dos juristas. Para ficar apenas num exemplo: poucos anos antes, a ditadura militar argentina havia virtualmente desmoronado, propiciando passagem muito rápida para um regime 
democrático. O ponto é que as negociações da transição e o programa do novo governo - sufragado, ao contrário do brasileiro, diretamente nas urnas -, não previam a convocação de uma assembleia constituinte. Ao invés de elaborar uma constituição "novinha em folha", os argentinos preferiram voltar à velha Constituição de 1853, naturalmente recheada com atualizações. E isso se dá apesar do caráter tão mais "rupturista" do processo argentino - em virtude da completa desmoralização das Forças Armadas que se segue à derrota argentina na Guerra das Malvinas -, o que, segundo as teorias constitucionais antes aludidas, justificaria, melhor do que no caso brasileiro, a invocação de um poder constituinte pleno, isto é, "originário", livre da tutela de qualquer legalidade antecedente ${ }^{9}$. De fato, a reforma constitucional argentina só entrou na pauta anos depois, envolvendo, aí sim, uma espécie de assembleia constituinte, mas já em outra conjuntura - não mais de transição propria336 mente - e servindo a outros propósitos.

Mas por que, afinal, a transição dos brasileiros teve uma constituinte e a dos argentinos, não? Teria sido por causa da propensão "legisferante" dos brasileiros, com suas frequentes "diarreias constitucionais", como afirmava o senador Roberto Campos (1994, pp. 1183-90) (embora ele estendesse a crítica aos latino-americanos em geral)? Ou por causa da reverência argentina às suas tradições fundadoras, que têm na Constituição de 1853 um marco crucial, associada como está à ultrapassagem da dicotomia federalismo-unitarismo que dilacerava o país até então (Coelho, 1999, pp. 107-8)? Pistas como essas, interessantes que sejam para nos lembrar dos fatores de longa duração, podem, todavia, nos distrair das circunstâncias especificas de cada processo, notadamente de suas contingências. $O$ presente trabalho

\footnotetext{
9 Para uma exposição do colapso da ditadura argentina e os eventos subsequentes, ver Novaro e Palermo (2007), capítulo 7.
} 
arrisca uma hipótese que as leve em conta. Por sua relevância para a discussão prometida no início do texto, há que se deter nela mais longamente.

A hipótese parte do seguinte dado: o regime autoritário brasileiro preocupou-se, muito mais do que o argentino, com sua própria institucionalização, através de normas e procedimentos que, para além da mera aparência de legalidade, servia a propósitos derivados da necessidade mesma de regular seus conflitos internos, como se verá adiante. É claro que nada disso retira o caráter essencialmente repressivo da ditadura que, através de instrumentos como o AI-5 e de uma máquina semiclandestina de perseguição aos opositores, podia suspender, da noite para o dia, todas as normas ou procedimentos e deixar qualquer cidadão à mercê de uma violência extrema, cuja simples ameaça já poderia dissuadi-lo de pendores oposicionistas. Porém, e a despeito disso, tais propósitos institucionalizantes, quando fazia sentido buscá-los com algum rigor, emprestavam à ditadura brasileira peculiaridades que a contrastavam com suas "primas" do Cone $\mathrm{Sul}^{10}$. E se essa busca fez, de fato, algum sentido na fase inicial do regime (antes da promulgação do AI-5), fez mais sentido ainda na longa fase derradeira, quando seus líderes passaram a se comprometer com um projeto de "distensão" ou "abertura" que, intencionalmente ou não, marca o início da transição para a democracia.

Além da volta à democracia plena, entre as possíveis consequências não intencionadas, há que se registrar a seguinte: ao manter o Congresso e seu calendário eleitoral e, ao mesmo tempo, criar um novo sistema partidário - primeiro em fins de 1965, como resultado do Ato Institucional n. 2 (AI-2), que levou ao bipartidarismo da Arena/MDB, e depois com a reforma de 1979, que sancionou um multipartidarismo limi-

\footnotetext{
${ }^{10}$ Até onde conhece o presente autor, a análise dessas peculiaridades e contrastes, pulverizada na vasta literatura sobre transições políticas, ainda está por ser feita de modo mais rigoroso e sistemático.
} 
tado - o regime permitiu o desenvolvimento de novas referências político-eleitorais. Estas encobriam, ou mesmo apagavam, as antigas referências nascidas do regime constitucional de 1946, ajudando a desmanchar, de modo talvez muito mais eficaz do que o puro e simples emprego do banimento e da força, as resiliências da memória popular no que diz respeito a seus velhos líderes e suas respectivas simbologias. A própria criação induzida de uma nova liderança de oposição (o MDB, e depois o PMDB e os demais partidos, particularmente o PT) gerava um incentivo autopropelido para diminuir o valor daquelas antigas lideranças. Ao contrário, os países em que ditaduras simplesmente aboliram o regime eleitoral e parlamentar, sem colocar nada no lugar, assistiram ao retorno das velhas agremiações partidárias, com seus símbolos e seus líderes ou herdeiros diretos.

Não por acaso, já em 1967, de acordo com o precioso estudo de Maria D’Alva Kinzo (1988, pp. 111-12) sobre o 338 MDB, a maioria desse partido se mostrava no mínimo relutante em cerrar fileiras com a Frente Ampla, que então unia contra a ditadura três das principais personalidades do regime de 1946 (Carlos Lacerda, Juscelino Kubitschek e Jango). Esse comportamento não se explica apenas pela disposição muito moderada do partido nessa época, mas também pela necessidade de autoafirmação de uma nova safra de políticos profissionais que encontravam, no sistema partidário recém-criado, uma brecha para florescer, a despeito de todos os limites do autoritarismo ${ }^{11}$.

\section{A natureza dual do regime autoritário e a dinâmica de sua "distensão"}

Ao longo do período autoritário, o MDB/PMDB tinha de ostentar dupla face: era, por certo, um partido de oposi-

\footnotetext{
${ }^{11}$ Para outra análise do papel das instituições eleitorais no regime autoritário, mas não divergente desta, ver Lamounier (1988).
} 
ção ao regime, isto é, contra o "sistema"; mas era também um partido de oposição do regime - uma "oposição consentida", como se dizia, obediente às regras estabelecidas, às quais devia sua própria existência - um partido do "sistema". Com a primeira face, a agremiação tinha de lutar por seus princípios e seu programa, os quais exigiam o pleno restabelecimento das liberdades civis e políticas e o fim da tutela militar - quer dizer, exigia nada menos que a substituição do autoritarismo em vigor por um regime democrático pleno. Com a segunda, porém, o partido atuava no sentido de fazer com que as regras o beneficiassem, embora a ditadura que as impunha, visasse exatamente ao oposto. Contudo, ao reconhecer instituições eleitorais, parlamentares e partidárias, o regime inscrevia não só a possibilidade de eleger candidatos parlamentares, mas também maiorias oposicionistas nas casas legislativas, inclusive no Congresso Nacional. Com maior dificuldade - que crescia conforme sua importância no plano nacional -, ele também previa a disputa do poder executivo: prefeitos, governadores e até o presidente da república; esse último, é claro, com chances ínfimas, por seu papel de principal sustentáculo do autoritarismo em sua expressão institucional. Em resumo, como partido de oposição do regime, o MDB/PMDB podia ao menos aspirar ao exercício do poder político conforme as regras estabelecidas; mas como partido de oposição ao regime, essa aspiração passava pela liquidação plena do autoritarismo, isto é, o fim do regime vigente. Como se vê, eram dois lados de uma mesma personalidade, porém nada fáceis de reconciliar.

Esses atributos, todavia, estavam longe de ser exclusivos do partido de oposição. Na verdade, eram reflexo da natureza dual do próprio regime autoritário que se estabeleceu no país. Dualidade por vezes recalcada, sem dúvida, mas que era sua marca de origem e de tal modo persistente ao longo de sua trajetória que, se a desprezássemos, seria muito difícil compreender não apenas sua longa duração, mas 
também a forma com que se gestou uma das mais poderosas alternativas de sua superação.

Como se sabe, o golpe de Estado que o impôs foi resultado de uma aliança entre parte da liderança civil do regime de 1946 e da facção então majoritária da alta hierarquia militar. Essa aliança, embora unida no propósito de derrubar o governo constitucional vigente, dividia-se a respeito de suas pretensões futuras. Na liderança civil prevalecia a ideia de um expurgo da Constituição de 1946, ainda que mantendo suas instituições básicas, em particular as eleitorais. O golpe, desse ponto de vista, manteria o padrão do intervencionismo pontual das forças armadas nas instituições da República, fosse para beneficiar uma facção de partidos, fosse para beneficiar a adversária. Isso, também cabe lembrar, já havia acontecido algumas vezes durante o regime anterior: em 1954, com o quase golpe que levou ao suicídio de Vargas; no ano seguinte, com a intervenção bem340 -sucedida do general Lott para garantir a posse de Juscelino Kubitschek; em 1961, para impedir a posse de João Goulart... Embora o expurgo de 1964 devesse ser bem mais profundo do que o de 1947, que colocou o Partido Comunista na ilegalidade, a pretensão da maioria civil, especialmente dos chefes partidários que visavam concorrer às eleições presidenciais seguintes, era antes deslocar as forças atuantes no regime de 1946 do que propriamente eliminá-lo ${ }^{12}$.

$\mathrm{Na}$ alta hierarquia militar, no entanto, prevaleceu algo bem distinto: em vez do padrão anterior das intervenções pontuais ("cirúrgicas"), agora as forças armadas deveriam exercer uma tutela contínua sobre a República, colocando-se definitivamente acima dela. Esse passo decisivo se dá logo no primeiro ato institucional da ditadura (depois

\footnotetext{
${ }^{12}$ Sobre os episódios anteriores a março de 1964, ver Skidmore (1976), capítulos III, IV, VII e VIII. Sobre as tensões entre lideranças militares e civis do golpe, além dessa obra mais antiga de Skidmore (1976, pp. 370-3), ver o recém-lançado livro de Farhat (2012, pp. 175-214).
} 
designado AI-1), proclamado em 9 de abril de 1964: não por acaso, feito por uma junta militar - sem dúvida, com a assessoria de juristas de convicção autoritária - que se autoproclamou o "comando supremo da revolução", sem qualquer participação das instituições republicanas. Com efeito, essa participação não se deu nem por meio do presidente da república, Ranieri Mazzilli, que, como presidente da Câmara Federal, substituiu o presidente deposto, sob a (falsa) alegação de vacância do cargo e nem, o que é mais significativo, por meio do Congresso Nacional, que, nas intervenções anteriores, pelo menos teve preservado o papel de oferecer uma solução constitucional para seus resultados e, portanto, manter a função de árbitro final dos conflitos, sempre sob a pretensão da continuidade constitucional ${ }^{13}$. Dessa vez, porém, os chefes militares, por meio de ato institucional, proclamavam unilateralmente uma ruptura, alegando encarnar a vontade nacional e sua capacidade de invocar o "Poder Constituinte", o que os colocava acima das instituições estabelecidas e da própria constituição. O AI-1, dizia, enfim, através de seus três únicos assinantes (o chefe de cada arma), que a corporação militar não deveria se subordinar sequer ao presidente da República, invertendo, assim, a hierarquia constitucional tradicional, que reservava ao presidente a função de chefe supremo das forças armadas.

A conciliação dessas duas pretensões divergentes sempre ocorreu precariamente, na base de improvisos. Mas o próprio texto do AI-1 já indica algo no sentido dessa conciliação. Pois além de reivindicar o "Poder Constituinte" da nação - a senha para as medidas ditatoriais propriamente ditas -, o texto admitia ainda a autolimitação desse poder, justamente a brecha que se abria para a institucionalização

\footnotetext{
${ }^{13}$ Sobre o menosprezo do "Comando Revolucionário" militar ao presidente e ao Congresso, na elaboração do AI-1, ver Gutemberg (1994, pp. 178-85).
} 
do novo regime. Nesse primeiro ato institucional, a base da autolimitaçao ainda era a Carta de 1946, modificada pela dilatação do Poder Executivo e o encolhimento do papel do Congresso Nacional, além da fixação de um prazo para aplicar as medidas de exceção, tais como cassar mandatos parlamentares e direitos políticos de qualquer cidadão ${ }^{14}$. Mais à frente, a Constituição de 1946 será definitivamente abandonada, mas a ideia da autolimitação persistirá, com a outorga da Carta de 1967. Note-se, porém, que os poderes excepcionais eram sempre atribuídos ao presidente da Republica, o que apontava por onde deveria passar o equilíbrio entre as diferentes pretensões dos aliados. Se por um lado, reconhecia-se a máxima autoridade de um cargo civil - a presidência da República - por outro, agora ela devia representar diretamente algo mais alto, a "revolução" encarnada nas forças armadas, sendo decorrência implícita a ocupação do cargo por um hierarca militar. Com isso salvava-se, 342 na aparência, a República, que requer a subordinação do poder armado ao poder civil (representado pelo presidente), mas também a própria hierarquia militar, que requer a subordinação de todos os oficiais, inclusive os chefes de cada arma, a um comandante supremo ${ }^{15}$.

\footnotetext{
${ }^{14}$ Ver o preâmbulo do AI-1, que a certa altura diz: "A revolução vitoriosa necessita de se institucionalizar e se apressa pela sua institucionalização a limitar os plenos poderes de que efetivamente dispõe (...) Para demonstrar que não pretendemos radicalizar o processo revolucionário, decidimos manter a Constituição de 1946, limitando-nos a modificá-la, apenas, na parte relativa aos poderes do Presidente da República, a fim de que este possa cumprir a missão de restaurar no Brasil a ordem econômica e financeira e tomar as urgentes medidas destinadas a drenar o bolsão comunista [...]. Para reduzir ainda mais os plenos poderes de que se acha investida a revolução vitoriosa, resolvemos, igualmente, manter o Congresso Nacional, com as reservas relativas aos seus poderes, constantes do presente Ato Institucional" (www.acervoditadura.rs.gov.br/legislacao_2.htm).

${ }^{15}$ É preciso lembrar que um dos fatos desencadeadores do golpe de 1964 foi a percepção generalizada de quebra da hierarquia militar, alegadamente estimulada pelo presidente João Goulart, em virtude de manifestações e protestos de suboficiais e praças, não autorizados por seus superiores e então transformados em revoltas - o que em linguagem militar queria dizer "motim". Sobre esses episódios, ver Ferreira (2011), capítulos 8 e 9.
} 
Dois dias depois do AI-1, o Congresso elegia indiretamente - conforme previa a Constituição de $1946^{16}$ - um presidente da República que era também um marechal, visto como líder, do lado militar, da aliança golpista. A escolha do candidato, no entanto, significou também uma solução de compromisso, desde que Castello Branco era avaliado como um chefe militar mais sensível e respeitador dos rituais das instituições civis, inclusive as eleitorais. Em seu discurso de posse, por sinal, ele prometia zelar pela normalidade de todo o calendário eleitoral, sem exceção do cargo que vinha a ocupar (Gaspari, 2002a, pp.119-20, 125). Como sabemos, isso não aconteceu nem para o presidente, nem para os governadores, mas se confirmou para os mandatos legislativos. Derrotados, em outubro de 1965, os candidatos da UDN (apoiados pelo governo) nas eleições para governador na Guanabara e em Minas Gerais, o regime, através do mesmo Castello Branco, decide impor seu segundo ato institucional (o AI-2). Este, além de extinguir os velhos partidos, substituía a eleição direta dos governadores e do presidente pela escolha indireta num colégio eleitoral. Com essa decisão, os militares apagavam de vez a esperança dos antigos chefes partidários, mesmo os que haviam apoiado o golpe de 1964, de concorrer às próximas eleições presidenciais: selava-se, então, a ruptura com o antigo regime e sua constituição ${ }^{17}$.

Seria enganoso, porém, reduzir todas as tensões internas do novo regime a um conflito entre civis e militares. Se é verdade que a liderança militar exigia poderes excepcionais para cumprir as metas da "revolução", não é menos verdade que ela também intuía a necessidade da institucionalização do regime. Não só para satisfazer os aliados civis, mas para preservar a identidade da própria corporação militar.

\footnotetext{
${ }^{16}$ Constituição dos Estados Unidos do Brasil (1946), art.79, §2.

${ }^{17}$ Mais sobre as circunstâncias que levaram à decretação do AI-2, ver Skidmore (1988, pp. 93-100).
} 
Esta, embora pretendesse encarnar os ideais "revolucionários" do movimento de março/abril de 1964, estava longe de funcionar como um partido revolucionário em sentido próprio - não importando aqui sua orientação ideológica, se de direita ou de esquerda -, com seus vínculos orgânicos com a sociedade civil e os movimentos de massa, seus líderes carismáticos e sua intensa luta ideológica interna, definidora das carreiras de seus quadros. Não: mesmo assumindo a cúpula do poder estatal, os militares brasileiros se pensavam como uma corporação estritamente burocrática, ciosa de regulamentos e de modos previsíveis de ascensão de seus oficiais. Em particular, receavam sua excessiva politização e, com isso, as chances da emergência de um líder carismático - mais à semelhança de um caudilho latino-americano do que de um chefe revolucionário - que liquidasse sua dinâmica burocrático-corporativa. Mas essas chances cresciam, e muito, precisamente na medida em que as forças armadas 344 assumiam diretamente o poder político. Pois, nesse caso, o perigo que corriam era o de transformar o regime, autoritário que fosse, numa ditadura autocrática, tal como (ao ver deles) havia sido a ditadura de Vargas. Se o regime haveria de ser ditatorial, que fosse a ditadura de uma oligarquia (a dos hierarcas militares) e não uma ditadura pessoal. Mas isso requeria regras, leis escritas e não escritas, que limitassem os ardis da autocracia; regras que teriam de se nutrir desse insólito intercâmbio entre os regulamentos da hierarquia militar e as leis da República.

Eis por que, do lado das instituições civis, a prática tradicional, anterior ao regime de 1946, de proibir a reeleição do presidente, foi mantida. Por isso, também, do lado da corporação militar, só generais da mais alta patente deveriam tornar-se presidentes - prática reforçada pela decisão, tomada ainda no governo de Castello Branco, de transferir automaticamente para a reserva os generais de quatro estrelas que estivessem exercendo essa função por um tem- 
po considerado longo demais, isto é, suficiente para tentá-los a cultivar uma lealdade dos subordinados a suas pessoas (Skidmore, 1988, pp. 104-5). Ainda do lado das instituições civis: embora seja obviamente exagerado afirmar que a preservação do Congresso e das práticas eleitorais, inclusive as de um partido de oposição, tenha sido decorrência exclusiva desses fatores, é certo, em contrapartida, que tal preservação não se resumia a mera fachada, apenas para satisfazer constrangimentos diplomáticos e de política externa. Para além das necessidades de legitimação interna do regime algo já bastante ressaltado pela literatura acadêmica, e que não se pretende contestar aqui -, há que se cogitar a hipótese de que tais instituições também servissem ao propósito de oferecer uma válvula de escape, ainda que estreita e muito controlada, para os conflitos internos da alta cúpula e de outras entranhas do regime. Com isso, os militares podiam manter e cultivar um canal de interlocução e, quando oportuno, de negociação, com as lideranças políticas civis que emergissem da nova institucionalidade. Essas, como observado, seriam justamente as que tivessem aceito, mesmo a partir do campo oposicionista, as novas regras do jogo e que reconhecessem nelas, pelo menos parcialmente, o futuro de suas carreiras: que se lhes admitissem, enfim, algum valor positivo, a ser resgatado "aqui e agora" ou mesmo em algum incerto futuro.

Dizer essas coisas não significa, absolutamente, esquecer ou subestimar os vários conflitos que tais instituições tiveram com a cúpula do regime. Esses conflitos foram, sim, graves e muito significativos. Entretanto, menos porque revelassem divergências fundamentais entre civis e militares ou entre o Congresso e o autoritarismo, ou mesmo entre a oposição parlamentar e o autoritarismo. Revelavam, antes, uma contradição interna ao próprio regime autoritário: a contradição entre o "poder constituinte da revolução" que atribuía a seus porta-vozes um poder virtualmente ilimi- 
tado e incondicional, acima dos poderes da República - e sua pretensão, que o presente artigo afirma ter sido real, e não um mero disfarce, de se institucionalizar. Isso explica, mais do que as medidas de punição aos dissidentes, os poucos, porém importantes, fechamentos temporários do Congresso, motivados pela sanha de punir, com a autorização congressual, um de seus membros, tentando forçar decisões tremendamente constrangedoras para a maioria situacionista. É que, em tais tentativas, o "Poder Constituinte" se confrontava não só com a oposição, mas com todo o sistema de partidos que o regime mesmo instituíra e que tinha na corporação parlamentar um de seus sustentáculos. Mesmo que fosse um membro da oposição o atingido, a questão concernia não apenas ao MDB, mas também à Arena. Em suma, ao conjunto do Congresso Nacional, que se via impelido a defendê-lo pelo simples fato de ser um integrante daquela corporação ${ }^{18}$.

346 Importante insistir, porém,em que o conflito envolvia igualmente, e de forma não menos significativa, o presidente da República em sua dual função de representar os interesses maiores da "revolução" e de empunhar a máxima autoridade da República. Foram inúmeras as vezes em que a pessoa do presidente se viu entre essas duas funções, geralmente cedendo à primeira. Quando não o fazia, enfrentava o risco de sua desestabilização ou contestação explícita por algum chefe militar (via de regra, o ministro do Exército) que o julgasse aquém de seus deveres revolucionários ${ }^{19}$. $\mathrm{O}$

\footnotetext{
${ }^{18} \mathrm{O}$ fechamento do Congresso mais conhecido por esse motivo foi o que levou à decretação do AI-5, em dezembro de 1968. Mas antes deste, e ainda no governo Castello Branco, o Congresso foi fechado em outubro de 1966 por conta da resistência do então presidente da Câmara dos Deputados (da Arena) à cassação de seis deputados federais da oposição (Skidmore, 1988, pp. 113-4).

${ }^{19}$ Os quatro volumes da obra de Gaspari (2002-2004) são fartos no relato e na análise desses episódios. Mas eles podem ser encontrados, esparsamente, em quase toda historiografia sobre a ditadura. Note-se que, com frequência, o ministro do Exército era um pretendente ao cargo presidencial.
} 
problema ia além da tão falada, e pouco escrutinada, disputa entre a "linha dura" e a "linha moderada" no interior das forças armadas. O fato é que todo suposto representante da "linha dura", tão logo se tornasse presidente da República, se via levado a envergar os trajes de "moderado". Não por conversão súbita de convicção ou de personalidade, mas porque assim impunha a tarefa crucial de improvisar um equilíbrio entre aquelas duas funções. Naturalmente, se o esforço redundasse impossível, passava, então, a ceder para um lado ou para outro ${ }^{20}$.

Mas não importa à análise aqui esboçada entrar nos detalhes dos acontecimentos examinados. O ponto central é o que nos revelam sobre a virada do regime, a partir do presidente Geisel, no sentido de sua "distensão" ou "abertura”. Costuma-se associar o projeto de distensão de Geisel ao processo de transição à democracia, como se uma coisa estivesse intencionalmente ligada à outra. Sem dúvida, sua firme disposição para abrir o regime é um dos fatores que desencadeiam a transição, mas é difícil crer que o presidente e seus conselheiros mais próximos a quisessem. Da perspectiva deste estudo, é mais plausível pensar a distensão como uma tentativa de resolver as pressões contraditórias da dualidade do regime, na direção de um reforço de seu lado institucionalizante.

Pode soar estranho afirmar algo assim a respeito de um governo que provavelmente tenha sido o que mais próxi-

\footnotetext{
${ }^{20}$ Exemplo notório: o presidente Costa e Silva que, mesmo depois da decretação do AI-5, buscava um modo de retornar, ainda em seu mandato, a uma normalização institucional (Skidmore 1988, pp. 191-2). É irônico constatar que o general Médici, o presidente dos "anos de chumbo", não fosse colocado em nenhum dos lados dessa divisa. Embora o mais popular, talvez tenha sido também o mais burocrático e anódino dos presidentes militares. Não por mera coincidência, ele fora literalmente escolhido por um "consistório" militar, antes de seu nome ser homologado pelo Congresso Nacional (Skidmore, 1988, pp. 196-201; Gaspari, 2002b, pp. 110-24).
} 
mo chegou, no período autoritário, de uma ditadura pessoal. De fato, o estilo centralizador e impositivo de Geisel, além do uso que continuou a fazer dos dispositivos do AI-5 - várias cassações de parlamentares e a imposição de legislação casuística via fechamento temporário do Congresso (o chamado "pacote de abril", de 1977) - projetou sobre seu governo essa imagem, parcialmente verdadeira, mas enganosa. Por mais paradoxal que pareça, esse estilo de governar talvez tenha colaborado com a persistência com que encaminhou seu projeto, mesmo quando este gerava inéditas tensões nas entranhas do regime.

Falar de "entranhas do regime" ajuda a compreender as razões e limitações da abertura que se pretendia realizar. Com efeito, o "Poder Constituinte" invocado pelas forças armadas, ao mesmo tempo em que autorizava medidas de exceção (legalizadas) contra os dissidentes políticos, solicitava o erguimento de uma complexa engenharia de repres-

348 são - um braço executor que, mais importante até do que as medidas punitivas, viabilizasse as ações tidas como "profiláticas”. Ou seja, demandava a construção de uma máquina especializada em moer dissidentes, reais ou supostos. E sem que fosse uma consequência necessária de qualquer ditadura - outras a construíram de modo diferente -, no Brasil (e um par de outros países latino-americanos) isso se fez a partir de dentro das forças armadas.

Havia, porém, um detalhe importantíssimo nessa construção. Todas as leis do Estado, mesmo os atos institucionais que o regime militar decretou, deveriam de algum modo atender ao princípio normativo da publicidade: serem amplamente conhecidas pelos cidadãos. Trata-se de um traço incontornável do Estado contemporâneo, enquanto artefato jurídico, que nem mesmo as ditaduras ousaram negar oficialmente e menos ainda um regime autoritário como o brasileiro, com suas pretensões institucionalizantes. Essa pressão normativa, no entanto, não podia valer exata- 
mente nesses termos para as operações da máquina repressiva, que, nesse sentido, tendia a tornar-se uma organização semiclandestina.

Tome-se, por exemplo, as práticas de tortura: desde pelo menos (senão antes) a Declaração Universal dos Direitos Humanos da ONU, elas não só são repudiadas pelo direito internacional, mas seu repúdio integra o quadro legal dos Estados nacionais que a endossam. Algo semelhante se dá com as práticas de escrutínio da vida privada dos cidadãos com fins de intimidação e controle político, de invasão de suas residências e de prisão sem o devido mandado judicial e tantas outras. Todas elas eram sabidamente empregadas e rotinizadas pelos aparelhos repressivos dessas ditaduras e também da brasileira. Porém, a despeito de sua suposta eficácia na repressão, eram inapelavelmente incompatíveis com a própria legalidade do Estado autoritário. Eis que tinham de operar de modo camuflado, à sombra das instituições oficiais que lhes davam cobertura.

Tais práticas, como sabemos, não são absolutamente estranhas nem mesmo aos Estados democráticos. Mas sob as ditaduras elas tendem ao paroxismo, exatamente porque autorizadas e incentivadas desde cima. A grande dificuldade dos que as autorizam, no entanto, é preservar seu controle, a fim de que não sigam além de certos limites, compatíveis com a integridade mesma do Estado. Entre outros requisitos fundamentais, falta-lhes justamente os instrumentos da legalidade, que a máquina repressiva tem, é claro, de dispensar, mas a que, em sua hipertrofia, começa a desafiar sistemática e arrogantemente, junto com as autoridades que viessem a representar essa legalidade, fosse ela autoritária ou não. É nesse ponto crítico que a criatura pode se voltar contra o próprio criador.

Que essa criatura seja inimiga de morte das liberdades básicas das instituições republicanas nem é preciso comentar. Menos óbvio é que ela se indisponha, como se indispôs 
no caso brasileiro, até mesmo com a corporação militar, que afinal a patrocinou. $\mathrm{E}$ aqui se faz necessário retomar o ponto, antes mencionado, da tradição eminentemente burocrática dessa estrutura, com seu apego aos regulamentos e à hierarquia.

A pleno vapor, a máquina de repressão semiclandestina, desembaraçada das formas públicas de supervisão, vai desenvolvendo uma espécie de hierarquia paralela dentro da hierarquia oficial - um "duplo comando", digamos assim. Em vez de reconhecido por sua patente militar, o soldado da repressão o é por sua importância na "comunidade" dos iniciados no combate aos dissidentes e por sua lealdade, fanática ou oportunista, a esse propósito. De modo que, ao dilatar-se, essa organização paralela acaba corroendo os princípios estruturantes da própria corporação militar, afetando, com grande desconforto, a identidade coletiva de seus membros. Como revelam os 350 depoimentos colhidos pela historiografia do período, esse problema foi muito sentido por diversos oficiais ciosos do profissionalismo militar ${ }^{21}$, especialmente nos tempos da repressão mais furiosa.

O programa da distensão "lenta, gradual e segura" do governo Geisel - depois metamorfoseado em "abertura" sob o governo de seu sucessor (general João Figueiredo) - fazia eco a esse sentimento difuso e a partir dele buscava apoio dentro das forças armadas. Mas a questão não poderia se restringir a uma iniciativa intracorporativa: se seu estopim era um descontentamento de natureza legal-burocrática, sua raiz tinha origem mais profunda e complicada, que chegava à arquitetura política do regime. Vale dizer: as relações promíscuas que se estabeleceram entre a hierarquia militar e os poderes da República.

\footnotetext{
${ }^{21}$ Entre os depoimentos, cabe mencionar o do próprio general Geisel (D'Araujo; Castro, 1997), em especial o capítulo 21.
} 
O problema da existência de uma máquina repressiva semiclandestina, nascida dentro das forças armadas, não era apenas o de fazer crescer um duplo comando na hierarquia militar. Esse fenômeno espelhava uma realidade politica mais ampla: a existência de uma "câmara escura" que, em nome das forças armadas - e se apropriando do monopólio da violência que o Estado lhes garantia - pairava sobre todas as instituições civis, exercendo sobre elas uma tutela contínua. Essa "câmara", essa espécie de "conselho dos cavalheiros Jedi" "22 da República brasileira, justificava sua existência pela necessidade de protegê-la de suas próprias debilidades - na prática, o álibi para tolher suas liberdades, até o ponto de torná-las uma mera caricatura. Esse trabalho corrosivo, como anotado, se fez sentir desde as primeiras manifestações públicas do regime: já no dia 9 de abril de 1964, apareceu na forma de um "comando supremo da revolução" e nas figuras oficiosas dos três ministros das armas que, juntos, editam o AI-1, à revelia do Congresso nacional e do presidente pro tempore (R. Mazzilli) que substituía o presidente deposto (Jango). Alguns anos depois, essa mesma câmara escura volta a se fazer sentir subitamente, quando da incapacitação física do presidente-marechal Costa e Silva, em agosto de 1969. Naquela ocasião, a Constituição que seu antecessor, marechal Castello Branco, através do Congresso, outorgara ao país (a Carta de 1967), estipulava a posse do vice-presidente, Pedro Aleixo, político conservador e ex-udenista, então nas fileiras do partido situacionista. Impedido de tomar posse, Pedro Aleixo foi ilegalmente mantido sob custódia em sua residência. Enquanto isso, o país tomava conhecimento de que uma junta militar, composta pelos três ministros das armas, através de um novo ato institucional - já se estava sob o AI-5 -,

\footnotetext{
${ }^{22} \mathrm{O}$ texto se refere ao roteiro do blockbuster de ficção científica criado por George Lucas, "Guerra nas Estrelas".
} 
governaria o país até que fosse escolhido um presidente da república de sua satisfação, além de outorgar uma emenda constitucional que manietava a própria Carta de $1967^{23}$. Como em abril de 1964, esses atos eram baixados por uma trinca de chefes militares, que os fazia em nome dos objetivos mais altos da "revolução".

O fato de ter brotado como do nada em duas ocasiões, não significa que essa câmara tenha existido esporadicamente e apenas nesses momentos mais dramáticos. Uma "câmara escura" é exatamente isso: age contínua, mas veladamente. Como tal, seu alvo mais importante não é nem o Congresso nacional, mas aquele que supõe ser seu representante direto nas instituições civis: o presidente da República. Por isso mesmo, era melhor que este fosse um camarada da caserna. O que, porém, não bastava: mesmo militar, era preciso que fosse colocado sob constante vigília, para obstruir qualquer veleidade de independência - para impedir, 352 em suma, que exercesse efetivamente a máxima autoridade da República, sem exceção das forças armadas, e que se curvasse apenas ao poder civil e às leis.

Note-se que não tivemos precisão, até aqui, de falar em democracia para escrutinar o que, afinal, estava implicado nas contradições do regime autoritário brasileiro e o que o projeto de distensão "lenta, gradual e segura" buscava, também contraditoriamente, resolver. É que de fato, como já se aludiu, não estava em seu horizonte o pleno restabelecimento da democracia, mas antes a afirmação de um processo institucionalizador inscrito no próprio regime. Essa institucionalização, porém, esbarrava no "poder constituinte da revolução”, com todas as suas consequências: além das medidas de exceção (legalizadas), a máquina de repressão (ilegal), e a tutela contínua, no mais das vezes invisível, da

\footnotetext{
${ }^{23}$ Para os detalhes desse episódio, ver Gaspari (2002b, pp. 82-6) e Skidmore (1988, pp. 192-6).
} 
"câmara escura" das forças armadas (acima da lei). Com efeito, ainda que o horizonte da distensão estivesse aquém da democracia, seus protagonistas eram obrigados a enfrentar o problema da autoridade da República, a começar a autoridade do presidente. Sem esse enfrentamento, o projeto aberturista não poderia prosperar e com isso o governo que o empunhava fracassaria por completo. Que essa iniciativa tenha levado a uma transição para a democracia e a um processo constituinte é questão adicional analisada a seguir. Por enquanto, concentremo-nos nos desafios intrínsecos ao programa da institucionalização autoritária.

No governo Geisel, restaurar a autoridade do presidente significou em primeiro lugar restaurar sua capacidade constitucional de chefe supremo das forças armadas. E ao fazê-lo, o presidente desmoralizava (embora não desmantelasse) o poder de pressão velada encrustado no interior da corporação militar. Isso, a despeito de que ele mesmo fosse um militar. Irônica e contraditoriamente, essa origem profissional agora se fazia em benefício do fortalecimento de uma instituição civil (a própria presidência da República): sua condição e experiência de militar talvez até o qualificasse, melhor do que a um paisano naquela conjuntura, para fazer o embate, pois conhecia por dentro o estado de espírito e a distribuição de forças da tropa. Mesmo assim, não era coisa das mais simples, naqueles tempos, substituir comandantes (como o do II Exército, em São Paulo) que não obedeciam as ordens presidenciais de enquadrar o Doi-Codi sob sua jurisdição ou demitir um ministro do Exército que pretendia sobrepor-se à sua autoridade ${ }^{24}$.

Mas esse, outra vez, era apenas um dos desafios da distensão, ainda que crucial. O outro, bem mais delicado politicamente, era restabelecer os demais poderes da Repú-

\footnotetext{
${ }^{24}$ Para os detalhes desses episódios, ver Gaspari (2004), partes II e IV. É ele quem observa que, tendo saído vitorioso desses embates, Geisel "restabelecera a autoridade constitucional do presidente da república sobre as Forças Armadas” (p. 481).
} 
blica. Delicado porque implicava devolver autonomia às instituições eleitorais e ao regime de partidos - quer dizer, deixar que as regras próprias a essas instituições seguissem livremente seu curso. Quanto a esse ponto, a questão não era sequer aceitar que um partido de oposição assumisse as rédeas do país; antes, o que estava em jogo era a ideia mesma de um governo de partidos: que seus representantes, a começar pelo partido situacionista, assumissem plenamente sua aspiração ao poder político. Pois, sob tutela militar, tanto o MDB quanto a Arena, estavam na prática impedidos dessa aspiração, mesmo que em tese as regras institucionalizantes do regime a previssem. Assim, enquanto partidos do regime, e a despeito de suas divergências eleitorais, MDB e Arena tendiam a formar uma aliança tácita nesse terreno. Por sua vez, o governo, se queria impulsionar seu projeto aberturista, tinha interesse em cultivar as aspirações de empoderamento desse campo, a fim de torná-lo interlocu354 tor relevante na negociação das reformas constitucionais necessárias à implementação do programa governista.

A distensão, todavia, teria de ser "lenta, gradual e segura” e é precisamente nessas qualificações de ritmo e prudência que podemos encontrar sua grande contradição. Pode-se dizer mesmo que essa era uma contradição especial dentro da contradição maior encravada na manutenção de um regime autoritário pela via da institucionalização. Ou, se quisermos sublinhar o difícil e novo equilíbrio que se buscava: era o problema de instaurar uma República "semiautoritária" ou "semidemocrática" - se se tratava do primeiro adjetivo ou do segundo, dependia de quem quisesse salientar a metade vazia ou a metade cheia do copo. Não importa: nenhuma das duas poderia ser, nem pretendia ser, uma candidata à altura dos valores de uma República democrática. Restava saber se algo assim pela metade seria viável na prática, em vista das contingências nacionais e internacionais. Mais do que isso: em vista das aspirações 
democráticas adormecidas nos interstícios da sociedade brasileira e que poderiam despertar com a própria abertura do regime. É nesse contexto que a agenda da transição e do processo constituinte começará a ganhar sentido - sem que tenha sido planejada pelos arquitetos da distensão - e, então, a colocar em xeque a sobrevivência do regime, mesmo sob sua pretensa nova roupagem.

\section{Processo de democratização e processo constituinte}

Não é fácil definir em abstrato o que seriam a "democracia" e as "aspirações democráticas" a que se tem aludido no texto até este ponto. Em geral, as teorias democráticas costumam estabelecer o conceito que lhes é central (o regime democrático) a partir de tipos ideais e sem considerar contextos específicos. O mesmo ocorre com os conceitos contrastantes (o negativo da democracia), tais como "ditadura" e "autoritarismo”. Em princípio, não há nada de errado ou criticável em fazer isso, em vista do caráter generalizante e típico-ideal das abordagens que, assim, conferem abrangência e rigor a seus conceitos. Contudo, essas virtudes cognitivas não raro são pagas ao preço da rigidez. Como a vida real dos regimes políticos, com suas historicidades específicas, frequentemente nos apresentam situações intermediárias, lusco-fuscos ou zonas cinzentas, o resultado é que situações assim acabam se tornando pontos cegos dessas teorias.

Todavia, essa é uma das dificuldades mais sérias a se enfrentar quando estudamos a política brasileira na conjuntura histórica tratada pelo presente artigo e que envolve justamente dar conta de um processo de transição de regimes políticos. Como a palavra mesma sugere, ela aponta para um lusco-fusco, uma zona cinzenta.

A questão de fundo da qualidade "lenta, gradual e segura" que se pretendia imprimir à distensão - uma abertura rigorosamente controlada - é que ela exigia que as regras, 
procedimentos e práticas apropriados à meta da institucionalização do regime produzissem os resultados esperados por seus condutores e no timing que lhes fosse conveniente. Em termos de conteúdo, institucionalizar o regime autoritário significava então "legalizar a revolução", constitucionalizar o "Poder Constituinte" cujos propósitos haviam sido a razão de ser do golpe de 1964, transformando em cláusulas pétreas sua legalidade: segurança nacional; rédeas curtas e firmes sobre todos os grupos sociais, associações, movimentos e demandas específicas ou universais; veto a cidadãos e correntes políticas consideradas subversivas e assim por diante. Além disso, a própria fúria repressiva do regime, com sua "guerra suja" aos dissidentes, gerou o problema da imunidade a seus executores e mandantes, o que a abertura almejada também teria de contornar.

Operacionalmente, a distensão "lenta, gradual e segura" implicava calibrar as regras, procedimentos e práticas 356 de mediação da luta pelo poder político, de modo a: 1) favorecer, ou tornar mais prováveis, os resultados eleitorais desejados, obviamente para beneficiar o partido situacionista no Congresso e nas demais casas legislativas, os candidatos a prefeito ou governador e, mais decisivamente, o candidato a presidente apoiado pela cúpula do regime e 2) ir alargando o conteúdo e o campo de validade das próprias regras e procedimentos, num ritmo compatível com seu controle a partir dessa cúpula ${ }^{25}$. Envolvia, portanto, a manutenção de um poder político suficientemente concentrado, capaz de resguardar a iniciativa governamental a cada novo lance do processo.

Mas em que sentido, então, esse modo de institucionalizar poderia se chocar com a questão democrática? Por certo, a democracia também implica uma institucionalidade - cer-

\footnotetext{
${ }^{25}$ Esse ritmo não precisava ser linear, mas, se necessário, podia evoluir à maneira de uma sanfona, tal como indicou a famosa metáfora das "sístoles" e "diástoles", empregada pelo general Golbery.
} 
tas regras, procedimentos e práticas compartilhadas, consistentes com seus valores básicos. Porém, da perspectiva da presente análise, o problema central não é contrapor, digamos assim, dois modelos "estáticos" de institucionalidade - o do regime democrático e o do regime autoritário, ou mesmo de um regime autoritário como o brasileiro. Mais esclarecedor no que diz respeito ao que estava em jogo, é contrapor dois processos, dois modos divergentes de realizar a institucionalização de regras, procedimentos e práticas, com a seguinte peculiaridade: é possível que certo processo de institucionalização comece de um modo e acabe sutilmente se transformando num outro modo, não só distinto, mas divergente do anterior. A inflexão ou mutação do processo, por sua vez, tem efeito decisivo sobre o conteúdo da institucionalização, afetando seu caráter autoritário ou democrático. Assim, modo de institucionalizar e conteúdo da institucionalização definem-se reciprocamente.

Ao ver do presente autor, foi aproximadamente isso que se deu na passagem do autoritarismo para a democracia no Brasil, ao longo da quadra histórica aqui enfocada. Trata-se, portanto, de se falar antes de democratização do que de democracia e de articular conceitos que explorem não tanto os pontos extremos e mais nítidos do processo, mas a passagem ela mesma, isto é, a transição.

Contudo, o que assinalaria a inflexão de um processo como o da distensão - aquele pretendido pela cúpula do regime autoritário - rumo a algo como uma democratização? Precisamente aquilo que poderia subverter os intentos da distensão: que os resultados desejados se tornassem indesejados ou que o esperado se tornasse inesperado, e que o ritmo de alargamento do conteúdo e campo de validade das regras fosse diferente daquele que a cúpula do regime queria manter estritamente sob seu controle. Em síntese, a mudança da determinação para a indeterminação do processo é o que faz o país marchar rumo à sua democratização, de tal 
maneira que, a partir de certo momento, difícil de indicar com precisão, nenhum ator ou agência relevante e nenhum dos lados em confronto ou competição se mostraria capaz de definir unilateralmente tanto os resultados quanto o ritmo do processo.

Escrutinando os principais fatos relativos a essa inflexão no caso brasileiro, pode-se observar que a discreta passagem da distensão para a democratização ocorre justamente com a perda gradativa de iniciativa política do regime - vale dizer, a perda de sua capacidade de concentrar poder político suficiente, a partir da cúpula, para operar sua própria institucionalização. Essa perda, ademais, corresponde a um deslocamento da própria indeterminação do processo, da periferia para o centro nervoso do Estado, movimento que se dá em zigue-zague, intercalado por avanços e recuos. Para apontar sumária e esquematicamente a sucessão dos fatos: ela começa com a derrota da Arena 358 para o MDB na eleição do Senado, em 1974; passa pela crescente incapacidade dos governos autoritários - de Geisel a Figueiredo - de enfrentar a seu modo a crise econômica e os conflitos sociais dela resultantes; pela derrota dos candidatos do regime nas eleições para os principais governos estaduais e a perda de sua maioria na Câmara Federal, em 1982; até culminar com a campanha oposicionista das eleições diretas e a consequente perda da capacidade do regime de fazer unilateralmente seu sucessor presidencial, em 1984-1985. É nesse contexto que, então, se abre oficialmente o processo constituinte, cujo desfecho, isto é, a Carta de 1988, marca também o final da transição, ou, pelo menos, a realização de sua principal tarefa: a superação definitiva do regime autoritário.

Para a compreensão do processo constituinte, em particular, segundo o quadro analítico e conceitual exposto, cabe voltar a considerar os processos de distensão e democratização a partir da perspectiva dos demais atores relevan- 
tes, para além da cúpula do regime autoritário. Em primeiro lugar, o partido situacionista (a Arena, depois PDS): é óbvio que o horizonte da distensão lhe interessava eminentemente, uma vez que reunia as maiores chances de ser o principal beneficiário das regras vigentes de exercício do poder político, especialmente (mas não só) o modo indireto de eleger o presidente da República. Em princípio, era possível fazer isso sem precisar negociar com o partido de oposição, bastando garantir sua unidade interna. Com o desencadeamento da democratização, porém - e na medida em que fica mais claro que as coisas seguem esse rumo o partido vai improvisar mudanças de comportamento, a fim de se adaptar à crescente instabilização de seu futuro e manter acesa sua aspiração ao poder político. Para começar, um estudado distanciamento em relação ao governo que devia sustentar no Congresso; distanciamento que cresce na mesma proporção em que aquele se vê obrigado a adotar medidas impopulares para enfrentar a crise econômica e social $^{26}$. Tratava-se, pois, de realizar a dificílima manobra de guardar essa prudente distância do governo, que lhe era conveniente, sem que isso ferisse, no essencial, a sustentação ao regime, afinal sua melhor esperança de exercício do poder político.

Ao fim e ao cabo, a manobra se revelou impossível, desde que as sucessivas dificuldades do governo no Congresso reforçavam a perda de iniciativa política do regime para operar sua própria institucionalização e, por conseguinte, para garantir os benefícios mais estratégicos e de longo prazo que o partido poderia esperar de sua sustentação. Como vimos, se a manutenção da iniciativa política implicava o poder político concentrado, a perda gerava, ao contrário, sua fragmentação. Essa última, por sua vez, prenunciava a

\footnotetext{
${ }^{26}$ Sobre o impacto da crise econômica e social, especialmente a partir do governo Figueiredo, ver Couto (2010, pp. 255-73).
} 
implosão da unidade do partido situacionista, seu principal trunfo para garantir exclusivamente para si a eleição do próximo presidente. Prova dessa comunidade de destino de governo e partido se dá antes mesmo da campanha pelas eleições diretas, quando o presidente da República, general Figueiredo, também presidente de honra do PDS, abandona a tarefa de conduzir sua própria sucessão, entregando-a inteiramente ao partido (Rodrigues, 2003, p. 37). Tão logo se confirmou a falta de coluna vertebral do PDS para exercer a autonomia outorgada, esse "lavar as mãos" do presidente deu a senha para que suas divergentes correntes e lideranças se sentissem liberadas para seguir seus próprios caminhos. E o sucesso popular da campanha das diretas ofereceu à parcela mais substancial delas a justificativa de escape e uma alternativa de sobrevivência, ainda que ao preço de exercer um papel mais subalterno na condução dos rumos futuros do país.

360 Antes de considerar essa espécie de sobrevivência do antigo regime - que se chamou inicialmente de Frente Liberal, transformada depois em Partido da Frente Liberal (PFL) - é preciso recuperar o fio da análise do partido ao qual se associou: o MDB/PMDB. Como se observou, ao longo da vigência do autoritarismo, o MDB teve de conviver com a ambiguidade de ser um partido de oposição $d o$ regime e de oposição ao regime. Nos anos mais ferozes da ditadura, essa ambiguidade lhe foi muito cobrada, desde que havia pouco o que fazer entre simplesmente colaborar e simplesmente rejeitar o regime como um todo - ainda mais enquanto a oposição armada se oferecia como uma competidora mais heroica, mesmo que condenada ao fracasso. Com o deslanche da distensão, no entanto, essa dupla face do partido se lhe tornou conveniente por oferecer espaços para denunciar o autoritarismo a partir de dentro do próprio "sistema", conferindo dividendos eleitorais e as correspondentes brechas institucionais (cadei- 
ras parlamentares e prefeituras), sem que essa mesma dualidade interna se transformasse, inicialmente, em dilemas práticos. Mesmo que o caráter estritamente controlado da distensão acarretasse reveses - pois as vitórias parciais oposicionistas levavam o regime a mudar subitamente as regras do jogo através de uma sobrelegislação imposta e casuística - os recuos de curto prazo acabavam produzindo avanços no médio e longo prazo, na medida em que o casuísmo só fazia expor à opinião pública os limites autoritários da abertura, causando mais e mais desgaste ao estoque de legitimidade do regime, com os subsequentes e deletérios efeitos eleitorais.

Precisamente essa estratégia bem-sucedida do partido - sua capacidade de pôr em xeque os limites da institucionalização autoritária -, no entanto, vai colocá-lo em seguida perante dilemas práticos graves, expondo o ser ou não ser de sua identidade dual. Note-se que as derrotas eleitorais do regime, mesmo quando amenizadas pelos casuísmos, eram um dos fatores de sua perda de iniciativa política. Em tese, a capacidade de iniciativa perdida poderia deslocar-se para o partido oposicionista. Mas se essa possibilidade, por um lado, aguçava sua aspiração ao pleno exercício do poder político, ainda que num prazo incerto, por outro, impunha-lhe fardos imediatos quanto à divisão de parte da responsabilidade - primeiro no Congresso, depois nos governos dos mais importantes estados brasileiros - para enfrentar os graves problemas do país, em particular a crise econômica e social. Porém, em que direção exercer esse deslocamento de iniciativa? Para acuar o regime até que não houvesse alternativa, senão sua derrocada ou substituição? Ou para continuar explorando os espaços oferecidos pelas regras do jogo, instáveis que fossem, alargando seus limites até que pudesse alcançar o centro nervoso do "sistema"? (Neste último caso, não tanto para pura e simplesmente "derrubar" o regime, mas para exercer o poder político que lhe era de 
direito segundo as regras vigentes, na condição de um partido político e aspirante a um governo de partido).

Mas adotar qualquer um desses dois caminhos distintos, firme e inequivocamente, era por demais arriscado. Radicalizar o combate ao regime, como pedia a esquerda do partido, poderia expô-lo a tensões internas insuportáveis - exatamente por ter um pé bem fincado no terreno institucional disponível -, a ponto de sua implosão, o que já devastaria as chances de vitória dessa estratégia. Mas agir exclusivamente dentro das regras oferecidas também era um salto no escuro: quanto mais penetrasse nas entranhas do Estado autoritário, mais apertado ficaria o funil que levava à cúpula do poder - atingindo máximo estreitamento no colégio eleitoral previamente esculpido para a escolha do candidato presidencial situacionista - e, portanto, mais incerta ou improvável sua vitória.

Dado que nenhuma dessas alternativas poderia respon362 der a contento seus respectivos e previsíveis impasses, a saída natural para o dilema seria encontrar um meio termo, quando algo assim estivesse disponível - e $s e$ viesse estar. De fato, a oportunidade apareceu, tão logo ficou claro que a vitória obtida nas eleições de 1982, por si só, não daria ao partido força suficiente para galgar a próxima e decisiva escala da hierarquia do regime: a própria sucessão presidencial. Daí a forte adesão interna que vai ganhar a ideia de uma campanha popular em prol de uma emenda constitucional, restabelecendo as eleições diretas para presidente da república ${ }^{27}$. Provisoriamente pelo menos, ela satisfazia as expectativas das alas divergentes do partido: ao mesmo tempo em que continuava a explorar os espaços institucionais disponibilizados - e no sentido de alargar seus limites -, a proposta significava, em si mesma, um golpe mortal no

\footnotetext{
${ }^{27}$ Para uma exposição do xadrez político que leva o conjunto das oposições à campanha das "Diretas-Já", ver Rodrigues (2003, pp. 15-38).
} 
regime, desde que curto-circuitava sua estratégia gradualista e abria a agenda da democratização a partir de um cargo crucial, fosse para freá-la, fosse, ao contrário, para acelerá-la - como certamente ocorreria, com a vitória de um candidato oposicionista por essa via. Além disso, a campanha propiciava interação positiva e intensa com um conjunto de atores que ajudava a emprestar alta legitimidade à atuação oposicionista, especialmente entre uma eleição e outra: a sociedade civil. Aliar-se a ela numa campanha popular aumentava o poder de pressão sobre o Congresso nacional, instância oficial de resolução da contenda. Porém, mesmo que a emenda constitucional não fosse aprovada - o que todos sabiam ser o mais provável, dado o quórum elevado que exigia - o efeito colateral da campanha seria imenso, tanto no sentido de alterar a correlação de forças do futuro colégio eleitoral, quanto no de tornar aceitável a participação de um candidato oposicionista nesse espaço, se ela servisse para impor uma derrota irreparável ao regime.

Desnecessário narrar aqui o desfecho bem conhecido desse capítulo da transição. Cabe apenas salientar dois pontos que muito interessam a este trabalho. Primeiro, que a essa altura o país já estava inteiramente mergulhado no processo de democratização: o simples processo de abertura do regime tinha ficado definitivamente para trás ${ }^{28}$. Segundo, que a vitória do candidato presidencial do PMDB no colégio eleitoral, Tancredo Neves, não resolvia de vez o dilema anterior do partido - antes, o empurrava para frente e de certa forma o aprofundava.

Como assim? É que o partido, mais uma vez, vencia por dentro do "sistema", mesmo contra a vontade da cúpula do regime. Mais do que isso: em aliança com parte de seu componente situacionista, atraindo para seu campo largas

\footnotetext{
${ }^{28}$ Embora seja muito difícil, como foi dito, indicar quando exatamente a etapa democratizante começou a acontecer.
} 
hostes da antiga Arena/PDS. Não era pouca coisa, mas também algo que revelava seu compromisso com o passado não propriamente com o passado autoritário, mas de qualquer modo com seu passado. Parágrafos acima, falou-se da dissidência do PDS que se unira ao PMDB - sob uma nova legenda, o PFL - como uma "sobrevivência do antigo regime”. Mas não seria exagerado dizer que o PMDB também o era, embora carregasse dentro de si o "vírus" democrático que contraditoriamente o propelia para fora do regime. Evidentemente, o partido, assim era não como um endossador do autoritarismo, mas como um ente que brotara de seu interior e conseguira crescer em tensa coexistência com ele, alargando os limites impostos até o ponto de seu trincamento: nesse preciso sentido, o PMDB era um herdeiro do "sistema". Por isso mesmo, essa herança não poderia ser pura e simplesmente renunciada, sob pena de estiolar uma personalidade, por dupla que fosse, conservada por tantos 364 anos a duras penas.

A aliança com os dissidentes do antigo partido situacionista não era, pois, apenas plausível e realista estrategicamente, mas reforçava os laços do presente com seu passado - sua identidade coletiva - por maior que fosse o constrangimento, perante a opinião pública e perante seus adversários, de se apresentar de mãos dadas com um antigo adversário eleitoral e de princípios programáticos. Acontece que os momentos de confronto recíproco eram os mais conhecidos de público. Menos conhecidos, porém não menos importantes, foram os momentos - talvez bem mais numerosos durante os intervalos eleitorais - em que se dispuseram a colaborar e a negociar, especialmente no Congresso, para evitar uma crise institucional, deslanchar uma lei de interesse comum etc. - em suma, criando uma espécie de amizade corporativa. Olhando desse ângulo, a convergência naquele contexto decisivo de passagem de regime parecerá menos estranha e surpreendente. 
O PMDB, portanto, tendo assim assentado sua dupla personalidade, tenderia a continuar com ela, mesmo após a vitória definitiva sobre o regime: o "sistema” já não existia mais enquanto constrangimento externo a seu agir, mas algo dele estava internalizado, lado a lado com seus tradicionais princípios em prol de um regime democrático, porém de feições ainda muito incertas. A consequência inevitável disso era a persistência de seus dilemas fundamentais, para os quais só restava administrar da melhor maneira possível. Poder-se-ia afirmar então que a abertura do processo constituinte era simplesmente o próximo encontro do partido - após a eleição presidencial de Tancredo Neves - com seus próprios dilemas, agora avolumados com seu novo aliado? Assim seria, se aceitássemos, sem mais, que uma agenda constituinte, e apenas uma, estava posta irrecorrivelmente. Por certo, uma ampla reforma constitucional teria de ser feita. Mas por que não fazê-la aos poucos, conforme as necessidades, desmantelando em cada nova etapa os andares e alicerces do edifício autoritário e colocando novos, democráticos, em seu lugar? Não fora assim relembre-se - que havia feito a Argentina, bastando para tanto tomar como plano de apoio uma velha constituição (a de 1853)? Por que o esforço concentrado, politicamente dispendioso e, ademais, tendente à volatilidade, de uma assembleia constituinte?

A assembleia constituinte, no entanto - e a maneira muito peculiar como foi convocada - apresentou-se como uma saída de meio termo para evitar que o partido agora governante, e a coalização que formara para sustentar o governo, se estiolasse entre alternativas muito divergentes entre si. Era um modo de contorná-las, evitando sua confrontação direta. Uma dessas alternativas seria tomar a pauta constitucional como que a partir do zero, desprezando o substrato institucional anterior, inclusive o Congresso nacional. 
Em termos simbólicos, mas nada desprezíveis, significava renunciar sem ambiguidades à herança institucional do passado; em termos práticos, era a proposta de uma assembleia constituinte "livre, soberana e exclusiva", calçada no conceito de um Poder Constituinte ilimitado e incondicionado - o Poder Constituinte "originário", como foi explicado no início deste artigo. A alternativa exatamente oposta era a de fazer uma grande emenda à constituição vigente (a Carta de 1967, modificada em 1969), usando as regras de emendamento por ela previstas. Isso levava, na prática, a nada além do que colocar o Congresso existente em regime de reforma constitucional, definitivamente limitada, no entanto, por uma constituição viciada pelo autoritarismo. Como se recorda, era o resgaste de uma proposta que teve sua origem nos tempos da abertura do regime, oferecida, com algumas variações - como aquelas disputadas entre Afonso Arinos de Melo Franco e Miguel Reale, já citadas - por juris366 tas mais ou menos simpáticos ao status quo institucional. Simbolicamente, significava um balde de água fria sobre as altíssimas expectativas democratizantes - inclusive de participação - da sociedade brasileira naquela conjuntura.

Tendo as duas alternativas opostas encontrado forte ressonância no interior do PMDB e da coalizão governista, a saída de seus líderes foi buscar uma solução que, na forma, se assemelhava à encontrada para lidar com a sucessão presidencial do general João Figueiredo. $\mathrm{Ou}$ seja, incentivando, outra vez em aliança com a sociedade civil, uma ampla campanha popular em favor de uma nova constituição. A campanha, porém, para que tivesse alguma chance de sucesso, teria de construir para si um foco e uma arena apropriados. Um foco, isto é, um embate não disperso, mas concentrado no tempo, com começo, meio e fim e uma arena, vale dizer, um espaço bem definido para a encenação dos embates, não fragmentado espacialmente. Em suma: uma assembleia nacional 
constituinte $^{29}$. Porém, uma assembleia institucionalmente enquadrada, que não rejeitasse de partida a herança institucional ambígua do passado. Modificada ou construída pelo regime autoritário, é verdade, mas que a oposição havia logrado alterar e alargar, intervindo de dentro do "sistema", o que lhe dava latitude para reivindicar como uma obra igualmente sua e não apenas do autoritarismo. Era isso que o Congresso e o regime de partidos - em mutação desde a reforma de 1979, que instaurou um multipartidarismo controlado - representavam e que a agenda constituinte poderia preservar, em nome dessa história.

Assim, para aplacar seus dilemas internos (e tal como na campanha das "Diretas-Já"), a liderança do ex-partido de oposição propunha mais uma vez, para a tarefa constitucional à frente, uma intervenção por dentro do quadro institucional vigente, com vistas a ultrapassar seus limites. Eis a fórmula final: uma nova constituição, feita pelo Congresso nacional transformado em uma assembleia constituinte, por seu turno, pressionada por uma campanha popular.

Mas se não é de modo algum acidental que a sociedade civil tenha se preparado para intervir no processo constituinte - acabando por fazê-lo com grande eficácia, em parte por ter aproveitado a brecha aberta por uma estratégia partidária -, não se pode desconsiderar que esse conjunto de atores, ao longo do enfrentamento à ditadura, foi acumulando grande prestígio e autoridade moral em todo país, atingindo seu clímax na campa-

\footnotetext{
${ }^{29}$ Para a indicação de evidências empíricas sobre a construção dessa estratégia pela liderança do PMDB, ver Martinez-Lara (1996, p. 38), que registra: "A assembleia constituinte era vista como uma garantia de que a eleição indireta [de Tancredo Neves] não teria efeitos desmobilizadores. O senador do PMDB Mario Covas afirmava que a assembleia constituinte fora proposta porque 'ela seria o motor para estimular a participação da sociedade na politica'. [...] Uma simples emenda constitucional não poderia produzir o mesmo efeito".
} 
nha pelas eleições presidenciais diretas. Essa autoridade moral se devia, entre outras razões, ao desprendimento com que grande parte de sua massa diversa de associados e de seus líderes pelejava pelas causas democráticas mais amplas, sem a expectativa de retorno em termos de um exercício futuro do poder político - como era de se esperar, ao contrário, das lideranças partidárias. E no passado autoritário o faziam, ademais, expondo-se a riscos de retaliação de um aparato repressivo, infinitamente maiores do que um eleitor que votasse na oposição correria, protegido que estava pelo voto secreto. Ademais, se dispondo a pagar por conta própria os chamados "custos de participação”, também maiores do que o gesto de selecionar um partido ou candidato e dirigir-se a uma urna para escrutiná-lo. É certo que, em plena vigência do regime democrático, a militância da sociedade civil tende a banalizar-se e mesmo desgastar-se. Contudo, durante 368 um processo de democratização - numa transição -, seu valor ético-político é dos mais elevados e reconhecidos, certamente maior que a atuação partidária profissional, ainda que oposicionista ${ }^{30}$.

Dado esse prestígio, também não é casual que os atores da sociedade civil pudessem se apresentar como uma expressão direta da vontade do próprio povo. Sabemos que essa sinédoque se presta a profundos equívocos e manipulações, mas que na passagem do autoritarismo para a democracia produzia efeitos práticos consideráveis. E de fato produziu ao longo do processo constituinte, contribuindo fortemente para alterar a correlação de forças da assembleia que elaborou a constituição, à primeira vista desfavorável às pautas apresentadas pelos militantes da sociedade civil, se fôssemos levar em conta apenas a distribuição de cadeiras entre os partidos. Há, pois, boas razões para afirmar que,

\footnotetext{
${ }^{30}$ Para uma análise mais extensa desse ponto, ver Araujo (2009).
} 
sem sua participação intensa, a Carta de 1988 não teria sido a mesma que afinal foi promulgada ${ }^{31}$.

A experiência constituinte como um todo, enfim, ajudou a prolongar a indeterminação do processo democratizante, indeterminação que naquele momento já poderia estar chegando ao fim - não fossem as peculiaridades aqui examinadas -, em beneficío da nova aglutinação de forças que passara a governar o país.

\section{À guisa de conclusão: o que é e por que Poder Constituinte?}

Resta, para finalizar, tecer algumas considerações sobre a questão do Poder Constituinte, discutida na primeira parte do texto, agora com o benefício da análise da transição brasileira e seu impacto na pauta constitucional que a desfechou.

Como se frisou no início, este artigo não pretendeu colocar em xeque a validade normativa do termo, tampouco sua importância para uma concepção democrática de construção de uma nova ordem política. Mas o trabalho procurou pontuar - mesmo sem ter sido esse seu principal objetivo -, através de um quadro sintético da experiência brasileira

\footnotetext{
${ }^{31}$ A distribuição dessas cadeiras resultou das eleições parlamentares de 1986, realizadas num clima bastante favorável à coligação governista (PMDB-PFL), graças, em particular, à ampla acolhida popular (até então) do Plano Cruzado. Convertidos os votos em cadeiras, o PMDB, com a primeira bancada, obteve sozinho um pouco mais do que a maioria absoluta do Congresso (logo, da constituinte). O PFL obteve a segunda bancada. Mas se o PMDB tinha a bancada mais numerosa, tinha também a mais dividida quanto às questões substantivas da futura constituição. Já os partidos nitidamente de esquerda não chegaram a somar $10 \%$ das cadeiras. Algumas pesquisas da época, que buscavam calcular a distribuição de forças segundo a clivagem ideológica prevalecente entre os representantes da assembleia, davam conta de que cerca de $70 \%$ deles pendiam para posições que iam do centro para a direita, o que fazia prever uma constituição de conteúdo bastante conservador. Essa previsão, como é sabido, não se confirmou. Ver Pilatti (2008), especialmente capítulos 1 e 2 e Martinez-Lara (1996), capítulo 4. Não obstante, ver também Coelho (1999), capítulos 3 e 4, para uma visão distinta sobre o peso e a coesão interna dos partidos para explicar os resultados do processo.
} 
que vai do golpe de 1964 ao início do mais recente processo constituinte de nossa história, em 1985, certos modos como "Poder Constituinte" foi empregado e interpretado por divergentes correntes políticas e ideológicas. De especial interesse, é o fato de tê-lo sido, com muita insistência e até sistematicidade, pelos que contribuíram para instaurar e, depois, para tentar manter inflexivelmente, um regime de orientação autoritária e conservadora. Surpreende, portanto, que depois de vinte anos em que nunca estivera ausente do léxico político, nem mesmo do oficial (pelo contrário, como se viu), o conceito de "Poder Constituinte" continuasse a ser amplamente empregado - as raras exceções apenas confirmam a regra - sem revisões críticas mais profundas sobre seu significado, abrangência, especificidades etc.

Encarcerado pelas teorias constitucionais excessivamente preocupadas com o formalismo jurídico do processo então em curso - algo que contaminava não apenas 370 as correntes de inclinação autoritária, mas também as de inclinação democrática e, como se chamou aqui, radical-democrática -, o conceito pouco ajudou a distinguir, em termos substantivos, os campos em disputa e, principalmente, o que estava concretamente em jogo na batalha pela nova constituição. Se é verdade que do debate emergiu uma divergência entre esses polos, sobre a oportunidade de seu emprego naquela específica conjuntura nacional - em princípio importante, por seus efeitos práticos -, essa divergência foi se diluindo rapidamente nas disputas subsequentes do processo. Instaurada a assembleia, como seria de se esperar, as questões de conteúdo da futura Carta é que passaram a ganhar mais e mais relevância.

O exame detalhado dessas etapas mais avançadas do processo constituinte não é objeto do presente trabalho. O ponto a salientar nesta conclusão é outro e não depende de nenhuma análise adicional de fatos, além da que já se fez anteriormente. 
Linhas acima, voltou-se a acusar o formalismo jurídico que cativou os debates, no início do processo constituinte. Mas, para além de sua pouca sensibilidade para com as sutilezas e sinuosidades da política concreta, haveria algo de errado no campo propriamente doutrinário que estivesse ligado a esse problema? Vejamos. As teorias do Poder Constituinte são geralmente pensadas como expressão jurídica da teoria (política) da soberania popular ${ }^{32}$. Em consonância com esse vínculo, os manuais de direito constitucional costumam dizer que o povo é o "titular" do Poder Constituinte. O que isso significa? Primeiro, que "o povo" é a fonte última de legitimidade de uma constituição. Segundo que, ao se visar à construção de uma ordem política, visa-se a uma prioridade ou escala de poderes, na qual o povo ocuparia uma posição "superior" ou "suprema" a que as demais deveriam se subordinar. Essa hierarquia equivale à oposição entre "poder constituinte" e "poder constituído", atribuída ao padre Sieyès (como esses manuais também nunca deixam de mencionar), que a lançou na aurora da revolução para defender a capacidade de o Terceiro Estado - identificado com "a nação" - dar uma constituição à França.

É curioso que, a despeito de sua origem profundamente democrática, desde muito cedo na história do constitucionalismo moderno surgiram interpretações autoritárias acerca do Poder Constituinte. Note-se, porém, que a oposição entre visões jurídicas democráticas e autoritárias não corresponde necessariamente à oposição esquerda e direita: vale lembrar que, ainda durante a revolução francesa, as correntes jacobinas fizeram um uso autoritário do conceito

\footnotetext{
${ }^{32}$ Alguns autores assinalam uma sutil diferença entre "soberania nacional" e "soberania popular". A nação refere-se ao conceito de uma comunidade "em sua permanência no tempo", enquanto o povo é essa comunidade no tempo presente, aqui e agora. A primeira parece remeter a algo mais abstrato, intangível, ao contrário do segundo. Ver Ferreira Filho (2007, p. 23) e Bonavides (2006, pp. 153-7). Para uma exposição do contexto francês dessa questão, ver Bercovici (2008, p. 134 e ss.).
} 
(Baker, 1989, pp. 882-95) ${ }^{33}$. Naturalmente com mais atraso, algumas interpretações autoritárias, mas de inclinação conservadora, se mostraram, ao longo do século XX, capazes de se ajustar aos tempos, assimilando o Poder Constituinte junto com o princípio da soberania popular. Essa conversão também aconteceu no Brasil, pelo menos desde os anos de 1920 (mas principalmente desde os anos de 1930) e deixou uma escola bastante influente ${ }^{34}$.

Contudo, é típico das práticas inspiradas na vertente autoritária se apropriar dessas ideias a fim de legitimar apenas seus primeiros passos, para em seguida realizar uma operação de substituição, na qual reduzem "o povo" a uma agência compacta, ágil e de mais fácil controle, em geral uma organização fechada e estritamente hierarquizada, fazendo dela seu porta-voz exclusivo. Na Europa, assim o fizeram a esquerda comunista e a direita fascista, sempre que as oportunidades apareceram, através de seus partidos 372 altamente disciplinados. No Brasil, essa primazia coube a uma direita autoritária não propriamente fascista, mas conservadora, através ou de uma elite civil em aliança com a hierarquia militar, na qual esta aparecia numa posição mais ou menos subordinada; ou o inverso, como ocorreu em 1964, quando os líderes militares da "revolução" tentaram transformar as próprias forças armadas - logo, a escala de seus oficiais - numa espécie de encarnação da vontade do povo, porém com as tensões internas, que o presente trabalho procurou analisar.

\footnotetext{
${ }^{33}$ Nesse texto, Baker expõe o desenvolvimento do conceito de soberania durante a revolução, mas chama atenção sobre como o pensamento de Sieyès é absorvido e reelaborado pelas correntes jacobinas.

${ }^{34}$ Entre as concepções autoritário-conservadoras que surgiram na Europa nas primeiras décadas do século XX, cabe mencionar a teoria constitucional de Carl Schmitt. Essa concepção fez discípulos no Brasil, entre os quais o jurista Francisco Campos - autor da constituição outorgada por Getúlio Vargas em 1937 e conselheiro do primeiro ato institucional do regime de 1964. Para um perfil, ver Bonavides (1985), cap. XXVII.
} 
Mais tarde, já durante a transição e antes do desmantelamento do regime, grupos civis, dentro e fora do partido situacionista, percebendo o fiasco da continuidade da tutela militar, tentaram mobilizar visões jurídicas autoritárias, porém mais amenas, para orientar uma reforma constitucional limitada. Por diversas razões, ainda não muito claras para esta pesquisa, o esforço não prosperou ${ }^{35}$. De qualquer forma, algo semelhante retornou no início do processo constituinte. A semelhança estava em que, em vez de invocar o poder constituinte para justificar uma legislação extraordinária, como fizeram os militares através dos atos institucionais, a invocação se fazia com fins defensivos, isto é, para propor uma reforma dentro da estrutura constitucional, positivada por esse mesmo poder nos anos autoritários. A ênfase recaía agora sobre a legalidade, e não sobre a legitimidade, e se valia do fato de a oposição, que passara a governar o país e se comprometera com a ideia de uma nova constituição, ter derrotado o regime através dessa legalidade.

E o que dizer das visões jurídicas adversárias, que se pretendiam democráticas, nesse mesmo período? Delas é preciso destacar, em primeiro lugar, a clara recusa daquela operação de substituição que transformava "o povo" numa agência fechada e hierarquizada, que então se tornava seu porta-voz exclusivo. Se, por razões práticas, admitiam a representação do povo numa assembleia constituinte, faziam-no insistindo na necessidade de que houvesse espaço para que o povo pudesse contestá-la, se assim achasse conveniente, de modo a preservar, no essencial, sua soberania ${ }^{36}$.

\footnotetext{
${ }^{35}$ Um dos propósitos do pequeno ensaio de 1981, de Faoro, em defesa de uma assembleia constituinte, mencionado na segunda nota deste artigo, foi justamente denunciar essa tentativa.

${ }^{36}$ Algumas vertentes mais rigoristas desse campo chegavam até a defender a tese do referendo popular para concluir corretamente um processo constituinte, mesmo depois que uma assembleia de representantes do povo tivesse aprovado o texto constitucional (Silva, 2000, pp. 75-8; Bonavides, 1985, pp. 260-2).
} 
Embora essas questões apontassem para importantes divergências teóricas e práticas com as concepções autoritárias, havia duas proposições de sentidos equívocos no conceito clássico de Poder Constituinte, que permaneciam intocadas mesmo nas visões mais democráticas - aliás, intocadas por ambos os campos em disputa. Cabe discriminá-las a seguir, visando também fazer-lhes algumas observações críticas que, porém, não têm nenhuma pretensão de novidade: algo mais ou menos na mesma direção já circulava nos meios acadêmicos, em particular a partir de uma literatura internacional proveniente de centros e autores europeus e norte-americanos ${ }^{37}$. Entretanto, em vista de sua pouca ressonância no debate jurídico aqui enfocado, é preciso resgatá-las, mesmo que sumariamente.

A primeira proposição é que o povo, "titular" do Poder Constituinte, reúne um "poder superior ou supremo", ponto que, no debate, embasava a tese de que a autoridade para 374 elaborar uma constituição, derivada desse poder, era "ilimitada e incondicional". Em termos práticos, isso presumia que o Poder Constituinte - ou, sendo impossível dispensá-los, seus representantes - teria legitimidade para propor ou realizar qualquer coisa, podendo desconsiderar qualquer limite normativo e fazer tábula rasa da institucionalidade antecedente. A segunda é a suposição mesma da existência de "um povo", como se a identidade dele consigo próprio estivesse desde sempre resolvida, a despeito de sua natureza coletiva. $\mathrm{O}$ mesmo vale para sua vontade, entendida como expressão dessa identidade. Nesse sentido, a autêntica vontade do povo só poderia ser una, assim como o próprio povo é "um" e a tarefa fundamental de seus representantes, em sua pluralidade, seria, quando não fosse autoevidente, encontrar essa vontade e mantê-la inviolada. Representar

\footnotetext{
${ }^{37}$ Para citar um exemplo eminente, já bem conhecido no campo democrático de esquerda: a obra de C. Lefort. Parte importante dela começa a ser traduzida no Brasil durante os anos 1980. Conferir, entre outros, Lefort (1983).
} 
"verdadeiramente", portanto, seria representar essa vontade, dada de antemão.

Vamos às observações críticas. Não é difícil perceber que essas ideias, a despeito de suas intenções democráticas, deixam ampla margem para apropriação ou usurpação autoritária. Pois, a menos que como um corpo coletivo, sem exceção de nenhum de seus membros, ele pudesse "presentificar-se" e, ainda assim, de modo uníssono, como saber com certeza qual é a vontade do povo? Essa operação vai requerer um intérprete, que terá de assumir que existe uma vontade do povo a ser descoberta e pronunciada - como se vê, porém, esse mesmo intérprete será seu potencial usurpador. Um democrata rigoroso, nesse caso, teria de recusar preventivamente o papel de intérprete e permanecer indecidido sobre o que fazer, até que o povo, ele mesmo, lhe indicasse sua vontade. Porém, ainda que houvesse algo como um povo que pudesse se tornar assim presente, por que supor que seja redutível à unidade, em vez de, ao contrário, assumir sua pluralidade incontornável?

Por outro lado, maior ainda é a possibilidade de usurpação autoritária, se se admite sem mais o caráter supremo do Poder Constituinte e sua capacidade de derivar autoridade ilimitada e incondicional para elaborar a lei máxima de um país. É como se as propriedades formais do soberano, nas teorias absolutistas de soberania, pudessem ser transferidas, ipsis literis, para o princípio da soberania popular. Mas, se o que orienta o conceito de Poder Constituinte é seu propósito de instaurar um regime democrático, há que interrogar de que modo se evita que tal formalismo se sobreponha à substância do conceito. Exatamente por conta disso, a aceitação ou invocação de um Poder Constituinte tem de estar condicionada a um exame dos valores ético-políticos inscritos na experiência política coletiva prévia que possibilitou aquele poder. $\mathrm{O}$ que importa considerar, antes de tudo, na sua emergência, não são suas propriedades formais (ilimi- 
tação, incondicionalidade ou o que for), mas se de fato a experiência política de que emerge está saturada de valores democráticos. A necessária incorporação desses valores para que se reconheça um Poder Constituinte, no entanto, já produz a demanda de submeter esse poder a um quadro normativo que, ao fim e ao cabo, redunda em limites para sua agência. Em outras palavras: o Poder Constituinte, ou seus representantes, não está autorizado a fazer qualquer coisa; em particular, não está autorizado a propor ou produzir leis que contradigam os valores em nome dos quais foi reconhecido e invocado como tal.

Por fim, os problemas relacionados ao conceito mesmo de "um povo". Este não poderia apresentar-se como se fosse o conceito relativo a um ente natural, um ser que existe ou não existe, independente da ação humana. O povo é um artefato, construído em sucessivas e contraditórias deliberações e ações coletivas, porém sem uma identidade prévia. 376 E assim como nenhuma deliberação e ação coletiva prescinde de princípios, regras e práticas aprendidas ao longo de gerações, inclusive as da representação, o processo de construção de um povo requer um mínimo de institucionalidade. Falar de um povo não é falar de um ser originalmente "desvestido", que depois é "vestido" com princípios, regras etc., como se pudesse permanecer o mesmo a cada nova roupagem. Ao contrário, o povo é construído no mesmo compasso em que é "vestido", e se transforma nessa trajetória. Sua identidade mutável se faz por conflito e cooperação entre seus membros, seus cidadãos em potencial, numa peleja constante de indivíduos e grupos - e é por conta disso, em primeiro lugar, que o jogo da representação se faz. Antes de representar "um povo", representa-se na verdade esse movimento divergente e plural de conflito e cooperação entre suas partes. A representação, portanto, não vem "depois" da identidade de um povo, mas é elemento integrante de sua busca, mesmo que nunca conclu- 
ída. Enfim, se não se trata de afirmar uma unidade prévia e dada do povo, não se trata também de negar de antemão a possibilidade de um processo de unificação, a ser entendido, porém, dinamicamente: um processo que se faz e se desfaz, para depois se refazer e assim por diante, como uma história de continuidades e rupturas.

Entretanto, como assinalado, todas essas observações críticas a respeito de "um povo", que deveriam rebater no conceito de Poder Constituinte, assim como as observações anteriores sobre o caráter ilimitado e incondicional que dele emanaria, parecem não ter ressoado no debate jurídico descrito neste artigo. Ao contrário, cada campo permaneceu encravado em seus pontos de partida: ou a preservação do status quo institucional, por um lado, ou a rejeição total desse status quo, por outro. Ambos, porém, reivindicando um "Poder Constituinte" - e ambos com qualidades formais semelhantes, como se indicou - para justificar essas alternativas opostas. Uma polarização que poderia ter travado seriamente o desenvolvimento da luta política, na época enredada não apenas nos desafios da reconstrução institucional, mas também numa gravíssima crise econômica e social, ainda indiferente às transformações de regime em andamento. Todavia, resta o fato de que a disposição majoritária do país era para que o processo constituinte seguisse seu curso. E assim se fez.

Mas o que, subjacente ao processo mesmo, empurrava para frente o embate por uma nova constituição, era o impulso democratizante que então animava a sociedade brasileira. Em vista da experiência política aprendida nos anos anteriores, as forças políticas que combatiam as tentativas de preservar o status quo institucional - em operação dentro e fora do novo governo, fosse no campo partidário, fosse no campo da sociedade civil - se sentiam muito confiantes para ultrapassar esses obstáculos, empregando a mesma estratégia e caminhando no mesmo terreno pelos 
quais o próprio regime autoritário havia sido ultrapassado. Movimentando-se, em suma, em compasso com o lusco-fusco da transição. Pelo mesmo motivo, dificilmente estancariam perante o "tudo ou nada" da rejeição completa do quadro institucional posto, em vista do alargamento já alcançado e das amplas chances de sua ulterior mutação, se nele se conseguisse concentrar o impulso democratizante antes mencionado. A razão para essa aposta, outra vez, era a mesma que havia levado o país da distensão "lenta, gradual e segura" para a democratização: que nenhum ator político relevante controlava unilateralmente o desdobramento do jogo. A corporação militar continuava influente, mas há tempos não mais exercia tal controle; o ex-partido de oposição, embora forte e numeroso, também não o exercia, por sua própria dualidade interna; enfim, tampouco a sociedade civil, pelo fato mesmo de não consistir de "um" ator, mas de uma pluralidade contraditória de atores. Em

378 suma: ainda vivia-se a indeterminação do processo. Se havia naquele momento um Poder Constituinte em operação, essa era sua fonte.

\section{Cicero Araujo}

é professor titular de teoria política do Departamento de Ciência da FFLCH-USP, e pesquisador do Cedec e do CNPq.

\section{Referências bibliográficas}

ARAUJO, C. 2009. "O processo constituinte: sociedade civil e povo na transição”. In: GOULART, J. (org.). As múltiplas faces da Constituição Cidadã. São Paulo: Cultura Acadêmica.

BAKER, K. M. 1989. "Soberania”. In: FURET, F.; OZOUF, M. (orgs.). Dicionário crítico da revolução francesa. Rio de Janeiro: Nova Fronteira.

BERCOVICI, G. 2008. Soberania e Constituição. São Paulo: Quartier Latin.

BONAVIDES, P. 1985. Política e Constituição: os caminhos da democracia.

Rio de Janeiro: Forense. 2006. Curso de Direito Constitucional. São Paulo: Malheiros.

CAMPOS, R. 1994. A lanterna na popa: memórias. Rio de Janeiro: Topbooks. 
COELHO, R. C. 1999. Partidos politicos, maiorias parlamentares e tomada de decisão na constituinte. São Paulo, 289p. Tese de doutorado. Faculdade de Filosofia Letras e Ciências Humanas da Universidade de São Paulo.

COUTO, R. C. 2010. História indiscreta da ditadura e da abertura. Rio de Janeiro: Record.

D'ARAUJO, M. C.; CASTRO, C. (orgs.). 1997. Ernesto Geisel. Rio de Janeiro: Fundação Getúlio Vargas.

FAORO, R. 2007. "Assembleia constituinte: a legitimidade resgatada". In: COMPARATO, F. K. (org.). A República inacabada. São Paulo: Globo, pp.167-265.

FARHAT, S. 2012. Tempo de gangorra: visão panorâmica do processo político-militar no Brasil de 1978 a 1980. São Paulo: Tag\&Line.

FERREIRA, J. 2011. João Goulart: uma biografia. Rio de Janeiro: Civilização Brasileira.

FERREIRA FILHO, M. G. 2007. O poder constituinte. São Paulo: Saraiva.

FORTES, L. R.; NASCIMENTO, M. M. (org.). 1987. A constituinte em debate. São Paulo: Sofia Editora.

FRANCO, A. A. M. 1982. "A constituinte instituída". Revista de Ciência Política, v.25, n.1, pp.3-17.

GASPARI, E. 2002a. A ditadura envergonhada. São Paulo: Cia. das Letras. 2002b. A ditadura escancarada. São Paulo: Cia. das Letras. 2003. A ditadura derrotada. São Paulo: Cia. das Letras. 2004. A ditadura encurralada. São Paulo: Cia. das Letras.

GUTEMBERG, L. 1994. Moisés: codinome Ulysses Guimarães. São Paulo: Cia. das Letras.

KINZO, M. G. 1988. Oposição e autoritarismo: gênese e trajetória do MDB (1966/1979). São Paulo: Vértice/Idesp.

LAMOUNIER, B. 1988. “O 'Brasil autoritário' revisitado: o impacto das eleições sobre a abertura”. In: STEPAN, A. (org.). Democratizando o Brasil. Rio de Janeiro: Paz e Terra.

LEFORT, C. 1983. A invenção democrática: os limites da dominação totalitária. São Paulo: Brasiliense.

MARTINEZ-LARA, J. 1996. Building democracy in Brazil: the politics of constitutional change, 1985-95. New York/London: St. Martin's Press/MacMillan.

MICHILES, C. et al. (orgs.). 1989. Cidadão constituinte: a saga das emendas populares. Rio de Janeiro: Paz e Terra.

NOVARO, M.; PALERMO, V. 2007. A ditadura militar argentina, 1976-1983: do golpe de estado à restauração democrática. São Paulo: Edusp.

PILATTI, A. 2008. A constituinte de 1987-1988: progressistas, conservadores, ordem econômica e regras do jogo. Rio de Janeiro: Lumen Juris. 
0 processo constituinte brasileiro, a transição e o Poder Constituinte

REALE, M. 1985. Por uma constituição brasileira. São Paulo: Revista dos Tribunais. RODRIGUES, A. T. 2003. Diretas já: o grito preso na garganta. São Paulo: Fundação Perseu Abramo.

SILVA, J. A. da. 2000. Poder constituinte e poder popular: estudos sobre a Constituição. São Paulo: Malheiros.

SKIDMORE, T. 1976. Brasil: de Getúlio a Castelo. Rio de Janeiro: Paz e Terra. 1988. Brasil: de Castelo a Tancredo. Rio de Janeiro: Paz e Terra. 